\title{
Sea Level Records on Ouvéa Island in New Caledonia
}

\section{Nils-Axel Mörner}

Paleogeophysics \& Geodynamics, Stockholm, Sweden

Correspondence to: Nils-Axel Mörner, morner@pog.nu

Keywords: Sea Level, Last Interglacial, The Holocene, Sub-Recent Sea Level, $17^{\text {th }}$ Century, The Present

Received: May 10, $2020 \quad$ Accepted: June 13, 2020 Published: June 16, 2020

Copyright $\odot 2020$ by author(s) and Scientific Research Publishing Inc.

This work is licensed under the Creative Commons Attribution International License (CC BY 4.0).

http://creativecommons.org/licenses/by/4.0/

\section{Open Access}

\section{ABSTRACT}

Ouvéa Island in New Caledonia emerges as a new sea level standard. It has excellent morphological records of former sea level positions at interglacial high-stands as well as records of Holocene changes in sea level from a maximum at about $+1.5 \mathrm{~m}$ via a significant $+70 \mathrm{~cm}$ level of sub-recent, probably $17^{\text {th }}$ century, age to a stable to falling sea level in present time.

\section{INTRODUCTION}

I first spotted the sea level records of Ouvéa Island on a Google map image with a spectacular view of a striking under-cut terrace at a level of about $+4 \mathrm{~m}$ (obviously representing the Last Interglacial from an $a$ priori point of view), and a distinct Holocene undercut terrace graded to present sea level. This gave such an impression that I simply had to go there and see for myself (Figure 1). In November 2018, the expedition came through. This paper gives a general report on the field observational data. Short reports on the Late Holocene changes in sea level have been presented before $[1,2]$.

\section{GEOLOGICAL SETTING}

New Caledonia lies in the SW Pacific (Figure 2). It includes the main Island of Nouméa-Koné (Grande Terre) and the Loyalty Islands of Ouvéa, Lifou and Maré (Figure 3). The capital Nouméa is located at $22^{\circ} 16^{\prime} \mathrm{S} 166^{\circ} 28^{\prime} \mathrm{E}$. The geology is described by for example $[3,4]$.

Geologically-tectonically, the area is composed of NW-SE trending basins and ridges: the Vanuatu Trench, the Loyalty Ridge hosting the islands of Ouvéa, Lifou and Maré, the South Loyalty Basin, the New Caledonia Ridge hosting the islands of Belep, Grande-Terre and Pines, and the New Caledonia Basin (Figure 4).

The geology of the Loyalty Ridge remains unclear [3]. The Loyalty Islands are primarily composed of Late Miocene to Pleistocene reefs covering a basement of volcanic rocks, chalk, basalt and limestone of Oligocene to Miocene age.

Andréfouët et al. [4] proposed that the Last Interglacial level in New Caledonia is to be found at about $+4-6 \mathrm{~m}$ (sometimes up to $+10 \mathrm{~m}$ ), the Last Glaciation maximum at about $-120 \mathrm{~m}$, and the Mid-Holocene maximum from \pm 0 to $+2 \pm 0.5 \mathrm{~m}$. All three levels must be considered preliminary and with significant 


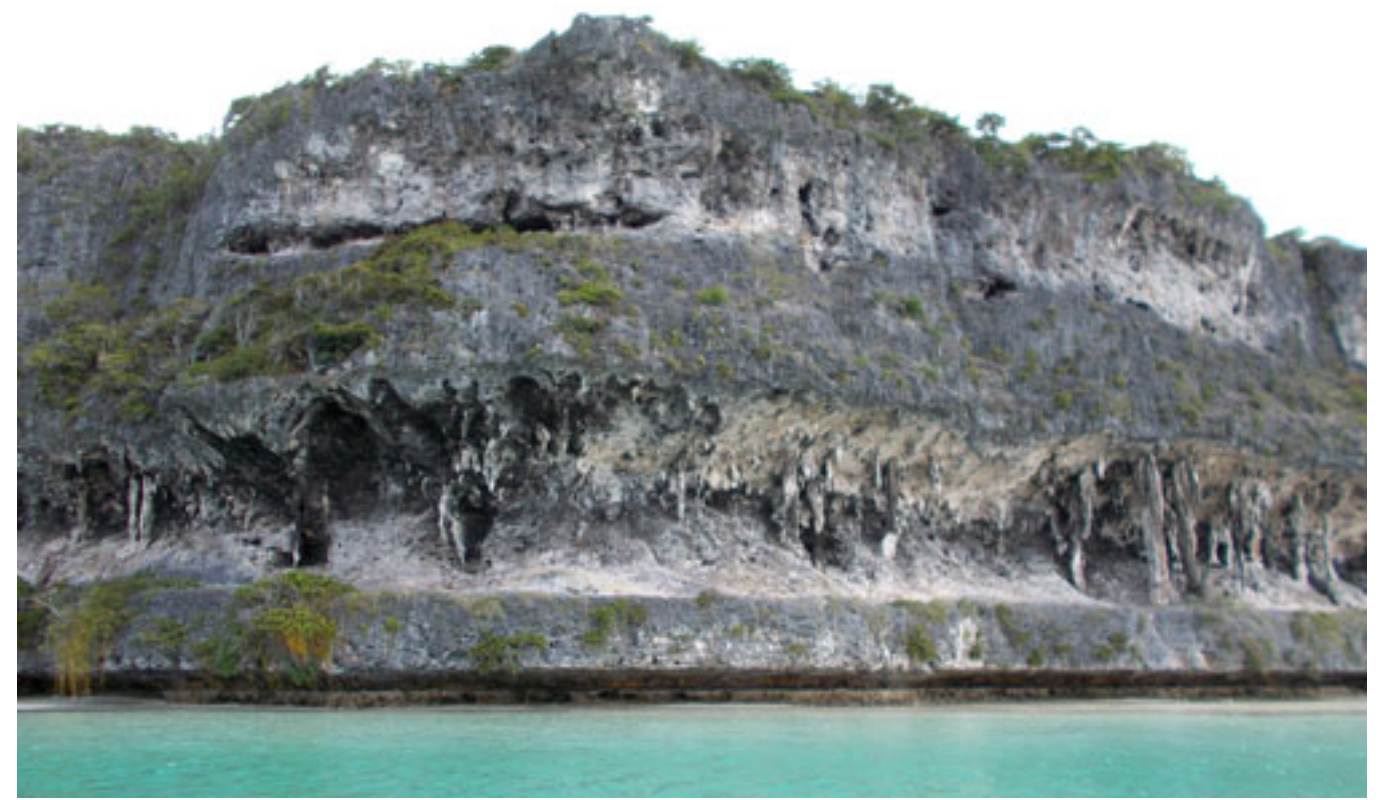

Figure 1. The spectacular Lekiny sea cliff on Ouvéa Island including 3 distinct sea levels: an upper $+22 \mathrm{~m}$ shore, a huge under-cut shore with rock-cut platform at $+4 \mathrm{~m}$, and Holocene to present under-cut shore. Picture taken at high-tide level on November 2018.

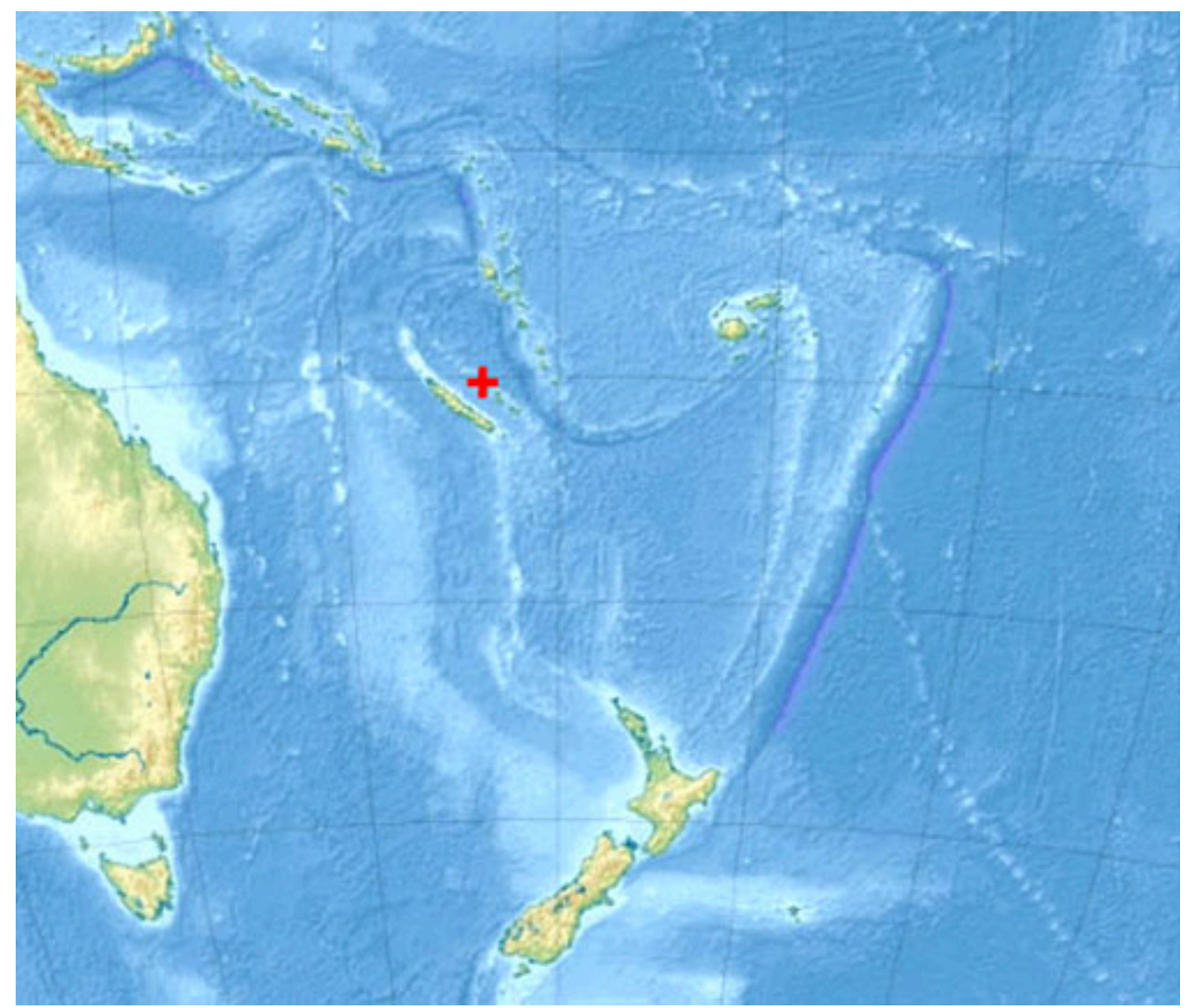

Figure 2. Location of New Caledonia (red + sign). 


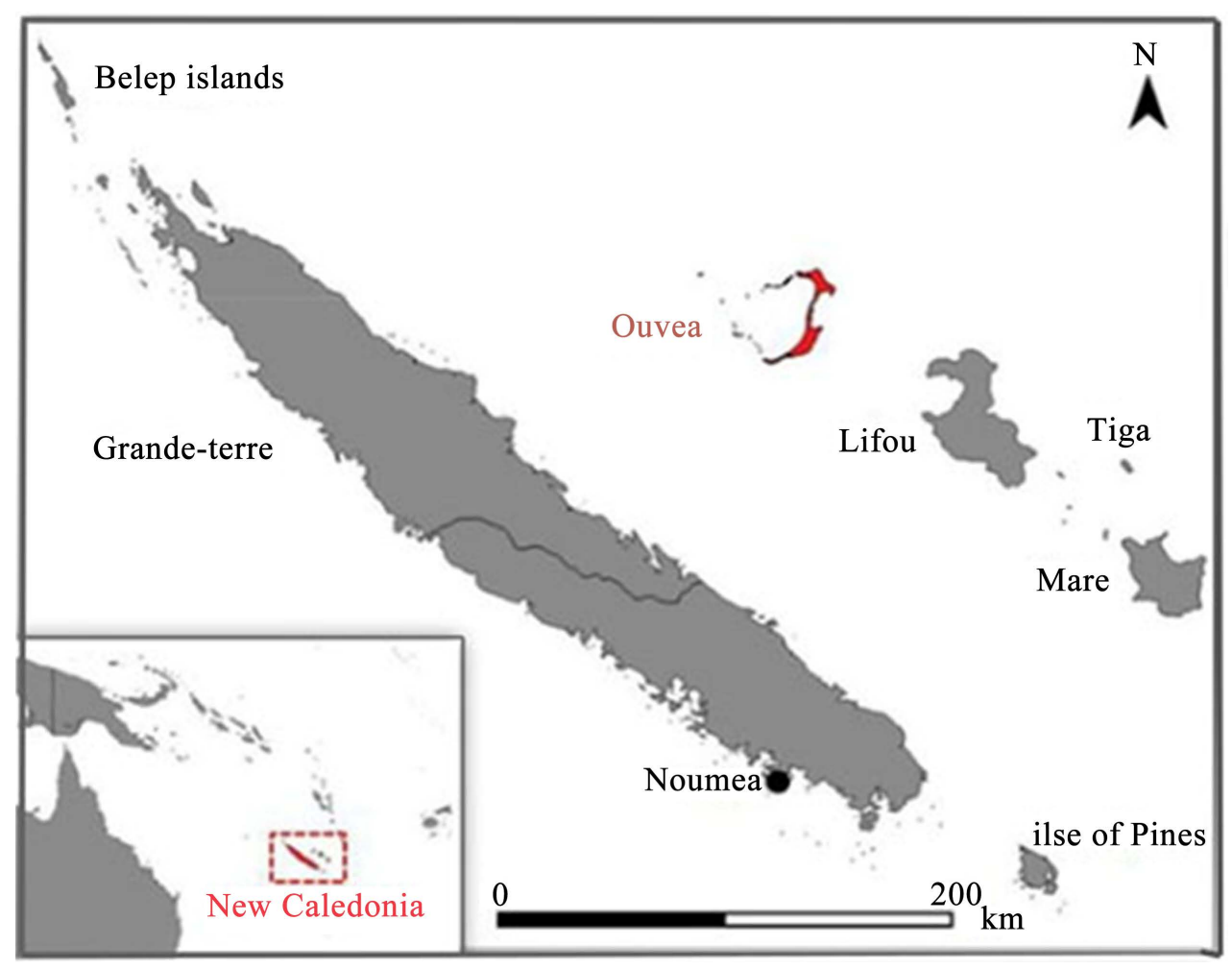

Figure 3. New Caledonia with the Ouvéa atoll marked in red.

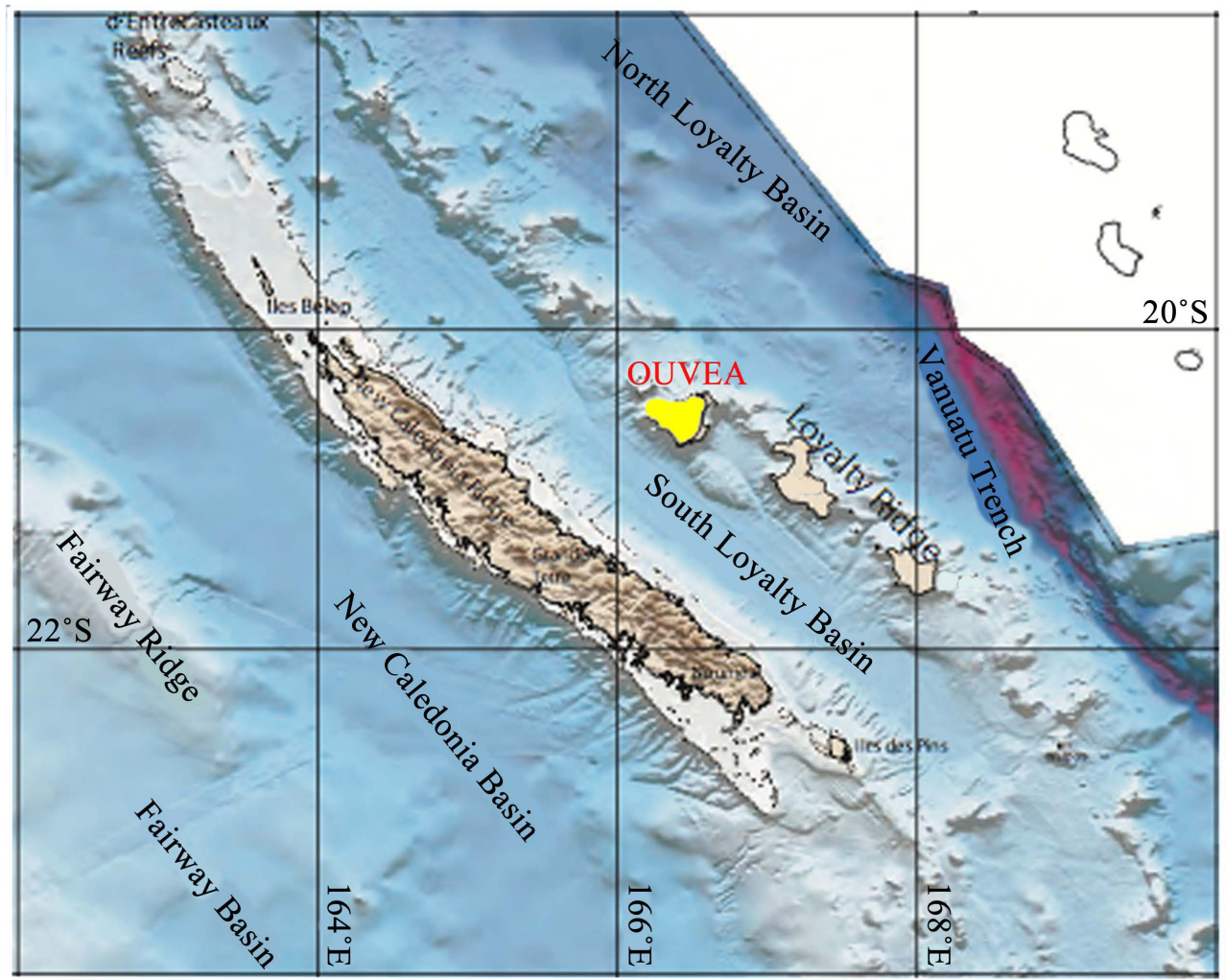

Figure 4. Geological-tectonical map of the New Caledonia region with ridges and basins trending in NW-SE direction [3]. The Ouvéa Atoll is marked in yellow. 
local variations. Figure 5 (modified from [4]) gives a preliminary account of the Holocene sea level changes in the southern part of Grande-Terre (and where the submarine levels seem too old for the levels marked).

This means that we a priori may expect to find a Late Glacial level in the order of $+4-6 \mathrm{~m}$, and a Holocene level slightly above the present (maximum $+2 \mathrm{~m}$ ).

\section{MATERIAL AND METHODS}

Before the expedition, I undertook a careful Google Earth map inventory of potential sites in addition to the Lekiny Cliff site of Figure 1. A literature survey was also performed with respect to New Caledonia in general [3,4] as well as to Ouvéa in particular [5-7]. Unfortunately, the Ouvéa material was very limited, almost absent.

In order to cover the entire island (30 km from north to south), I rented a car. A campsite was established at the Lekiny shore (Site 3 in Figure 6). The fieldwork was simple: driving, walking, observing, documenting, photographing, levelling, and sampling when appropriate. Investigations were performed at 20 sites (Figure 6). All photographs (except one) were taken by the author in November, 2018.

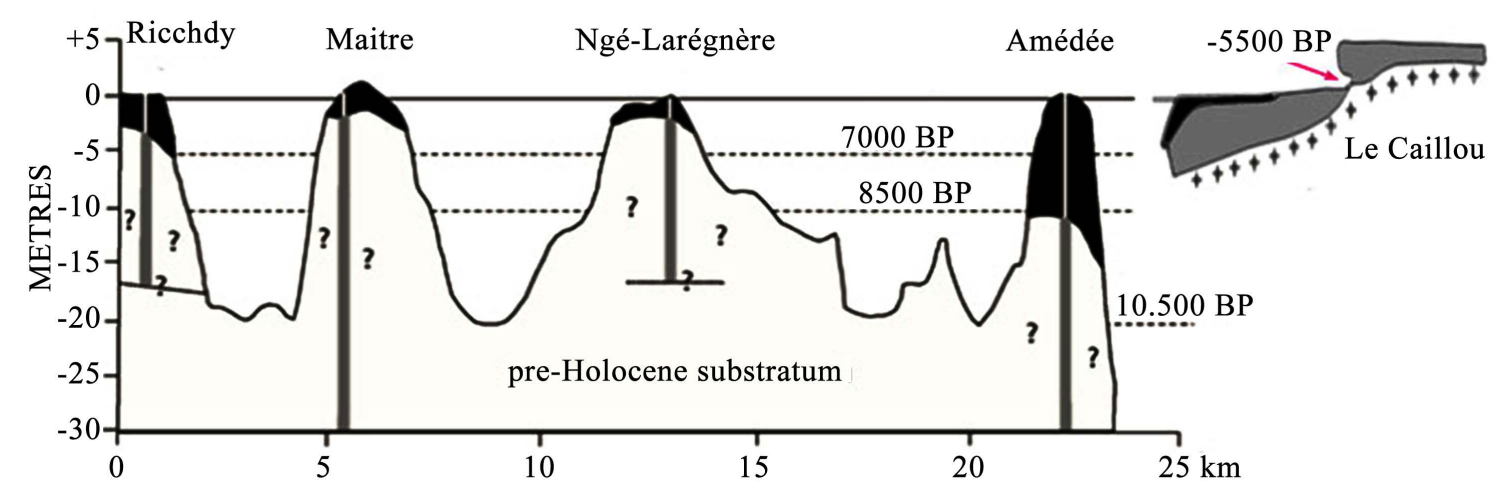

Figure 5. Compilation of Holocene sea level records from southern Grande-Terre [4].

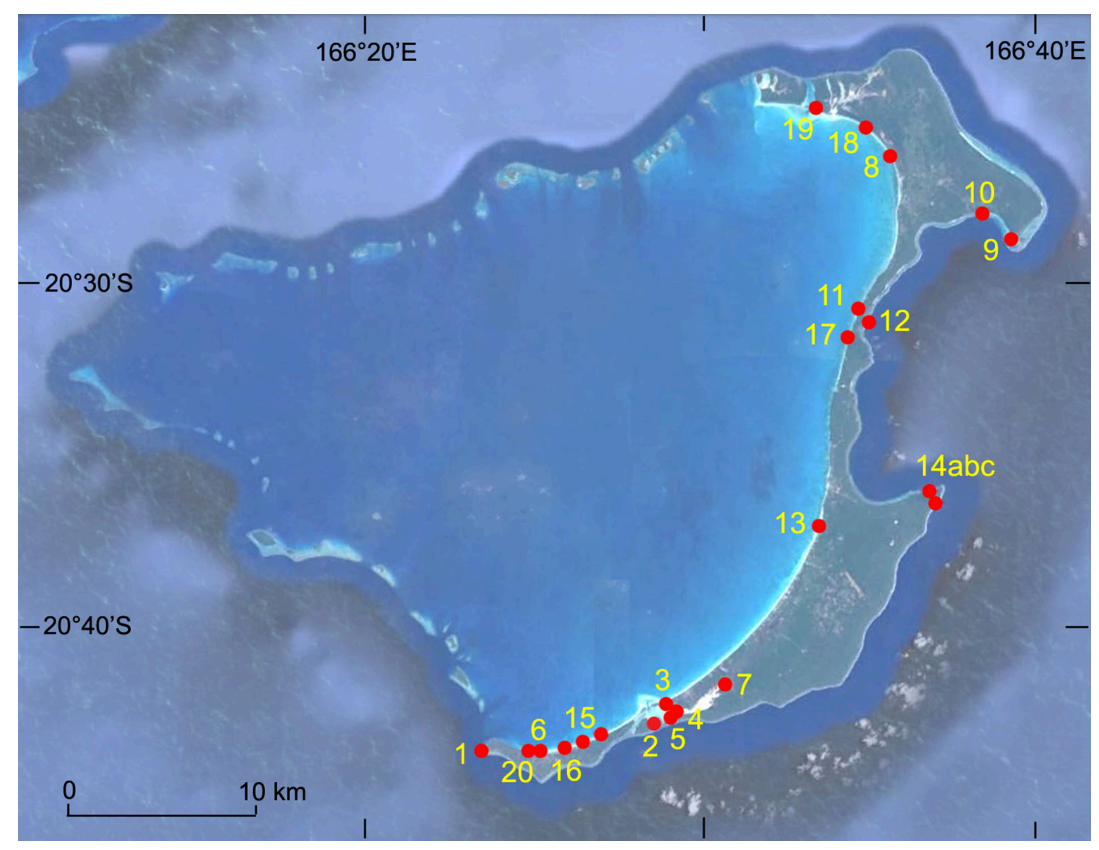

Figure 6. Ouvéa Island with the location of the 20 sites investigated. 
Because there is tribal land autonomy, some of the sites had to be visited with local guides, viz. Site 5, 14 (and 19, because of danger). Levelling was undertaken with a Bosch instrument, or a simple hand leveller. Two samples were subjected to C14-dating.

\section{RESULTS: THE PRE-HOLOCENE SEA LEVELS}

Starting with a general account on the Lekiny Cliff section (4.1), we proceed with analyses of the sites referring to the Last Interglacial levels $(4.2-4.7)$, and then turn to the sites of Holocene to present sea level records $(5.1$ - 5.16).

\subsection{The Lekiny Cliff (Site 5)}

The first and most important thing to do was to infer proper elevation of the Lekiny Cliff by high precision levelling (Figure 7). levels:

By levelling, we now have the total elevation of the cliff $(30 \mathrm{~m})$ and the elevation of three distinct sea

1) $A+22 m$ shore with sea caves and under-cut erosion

2) A very prominent shore divided in two phases; a huge under-cut shore from $+13 \mathrm{~m}$ to $+8-9 \mathrm{~m}$ with extensive stalactite columns from the overhanging roof, and a rock-cut platform at $+4 \mathrm{~m}$ (later more precisely fixed at $+4.3 \mathrm{~m}$ ).

3) A Holocene to present under-cut shore divided into two levels; an abandoned higher notch, and a present sea level $70 \mathrm{~cm}$ below.

The $+22 \mathrm{~m}$ shore seems significantly older and more weathered than the $+4-9 \mathrm{~m}$ shores. Wheatear it represents MIS 11 or the Pliocene $3 \mathrm{Ma}$ event [8] is hard to decide, however.

The second level is double: $+8-9 \mathrm{~m}$ for the extremity of the huge under-cut overhang, and $+4 \mathrm{~m}$ for the distinct rock-cut platform. It seems reasonable to assumethat these levels represent the Last Interglacial; maybe stage $5 \mathrm{e}(+8-9 \mathrm{~m})$ and $5 \mathrm{a}(+4 \mathrm{~m})$. It corresponds to the Last Interglacial level proposed by Andréfouët et al. [4] for New Caledonia in general at "about $+4-6 \mathrm{~m}$ (sometimes up to $+10 \mathrm{~m}$ )".

The $+4 \mathrm{~m}$ rock-cut platform (cut into an older reef formation) is connected to a shore cave (Figure 8), which has its floor (yellow + in Figure 8) levelled at $+4.3 \mathrm{~m}$. This level seems to be a good approximation of mean sea level at the time of formation. This level is likely to represent a second lower sea level of the Last Interglacial; maybe stage 5a from about $80 \mathrm{ka}$.

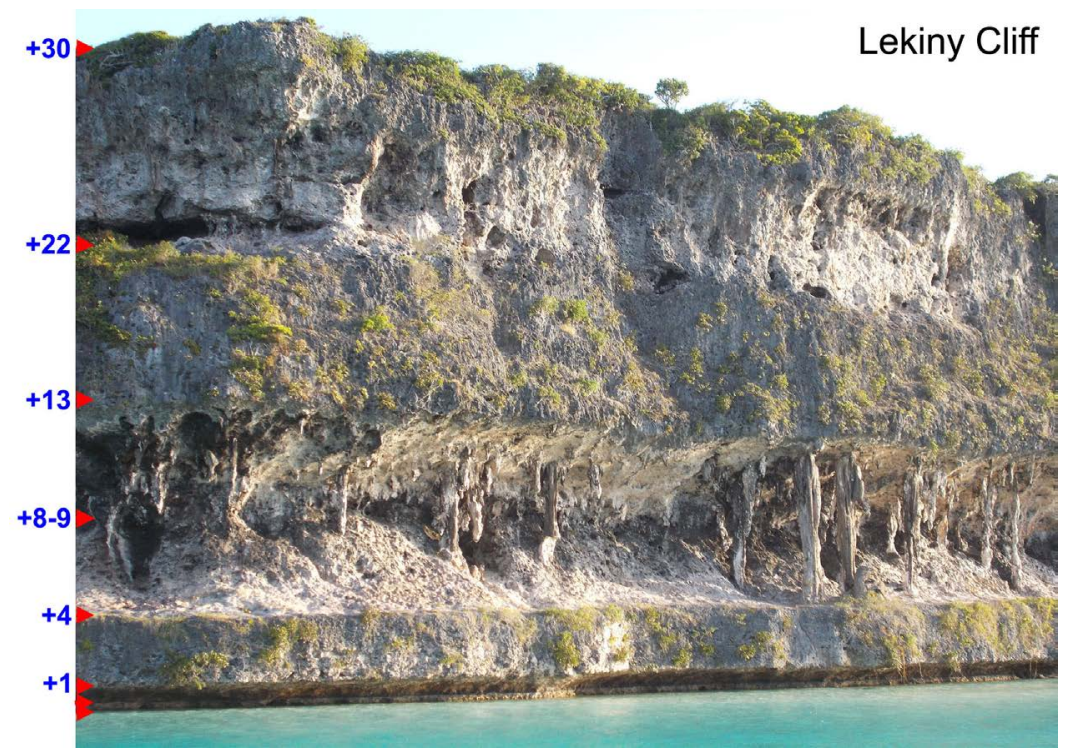

Figure 7. The Lekiny Cliff (Site 5), now with absolute elevation levels. 


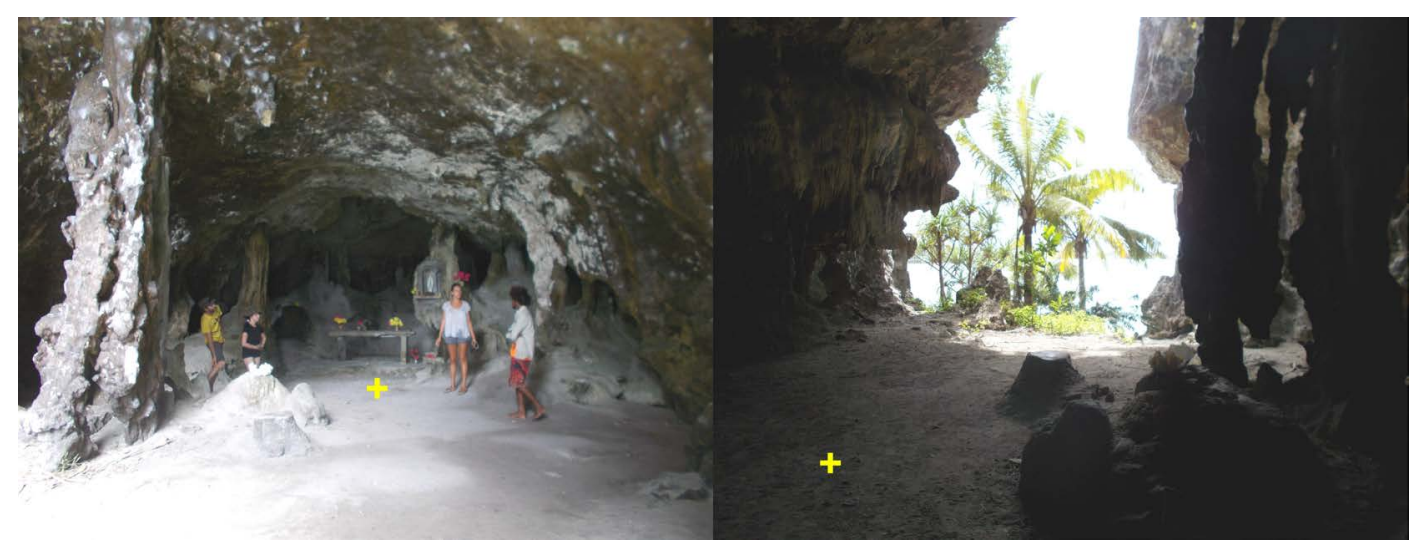

Figure 8. The Shore cave in association with the $+4 \mathrm{~m}$ rock-cut platform. The floor $(+)$ has an elevation of $+4.3 \mathrm{~m}$, which is a good approximation of mean sea level at formation.

\subsection{Cape St. Hillaire (Site 14)}

On the Google Earth map, one can follow three shorelines from Site 5 (Lekiny Cliff) all the way up to Site 14 (Cape St. Hillaire) on Figure 6. The Cape St. Hillaire area is closed to the public thanks to tribal autonomy. Mr. Mathius Waneux, the nearby farmer, kindly guided me around the peninsula. The main features are seen in Figure 9: an elongated ridge of land above the $+22 \mathrm{~m}$ shoreline, an extensive rock-cut platform bounded by a distinct shore cliff and a number of huge free-eroded blocks in the northwest, and six sites $(1-6)$ to be discussed below.

The present shore (at the red dot in Figure 9) has an extensive under-cut notch at high-tide level (HTL). There is an older rock-cut platform surface at about $+2 \mathrm{~m}$, which is likely to represent the Holocene maximum sea level. From about $+3 \mathrm{~m}$ the old reef-surface is deeply weathered and has dissolution hollows, which seem indicative of a pre-Holocene age. At $+4 \mathrm{~m}$, the old $\mathrm{E}-\mathrm{W}$ shoreline and $+4 \mathrm{~m}$ rock-cut platforms form a paleo-shore.

The rock-cut platform in the NE is extensive. Its more or less flat platform surface is at about $+4 \mathrm{~m}$ (obviously, it correlates to the $+4 \mathrm{~m}$ rock-cut platform in Lekiny Cliff (Figure 7). The surface is full of karstic dissolution holes, 0.5 to $1 \mathrm{~m}$ wide and at least $2 \mathrm{~m}$ deep (Figure 10).

At point 2 (Figure 9), there is a double notch in the old shoreline cliff (Figure 11), about $2.0 \mathrm{~m}$ above the cliff foot. Its level of about $+6 \mathrm{~m}$ falls within the shore complex at Site 5 .

Between points 2 and 3 (Figure 9), there is a huge separate block, which is surrounded by the rock-cut platform, and has a distinct hanging shore notch all around at an elevation of $4-5 \mathrm{~m}$ above the rock-cut platform. It implies that the block existed as a separate block both at the time of the formation of the $+9 \mathrm{~m}$ notch and the $+4 \mathrm{~m}$ platform. The notches in the big block are quite large (more of the type seen in Figure 12), and singular, which suggest that the double notches in Figure 11 represent a special case; either a higher event of the $+4 \mathrm{~m}$ stage, or a lower event of the $+8-9 \mathrm{~m}$ stage.

In the big blocks on the east side (point 3), there are extensive notches in the cliff bounding the $+4 \mathrm{~m}$ rock-cut platform. Figure 12 shows the hanging notch with later stalactite formation. Figure 13 and Figure 14 gives the view of the north-eastern shore with the $+4 \mathrm{~m}$ rock-cut platform, an extensive $+9 \mathrm{~m}$ paleo-shore notch, and an old $+22 \mathrm{~m}$ shore (surrounding an SW-NE trending land ridge as shown in Figure 9).

The $+4 \mathrm{~m}$ platform was measured from the present HTL. The notch was measured from the platform (with a Bosch instrument) at about $+9 \mathrm{~m}$ (or $9-10 \mathrm{~m}$ ). The shorelines can be followed down to Lekiny Cliff, where they correlate with the $+4 \mathrm{~m}$ rock-cut platform, the $+8-9 \mathrm{~m}$ hanging notch and $+22 \mathrm{~m}$ hanging paleo-shore.

At point 6 , in the forest to the west of the land ridge above the $+22 \mathrm{~m}$ shore (Figure 9), there are huge karstic caves (Figure 15) indicating a long time of terrestrial conditions with karstic dissolution and formation of stalactites and stalagmites. 


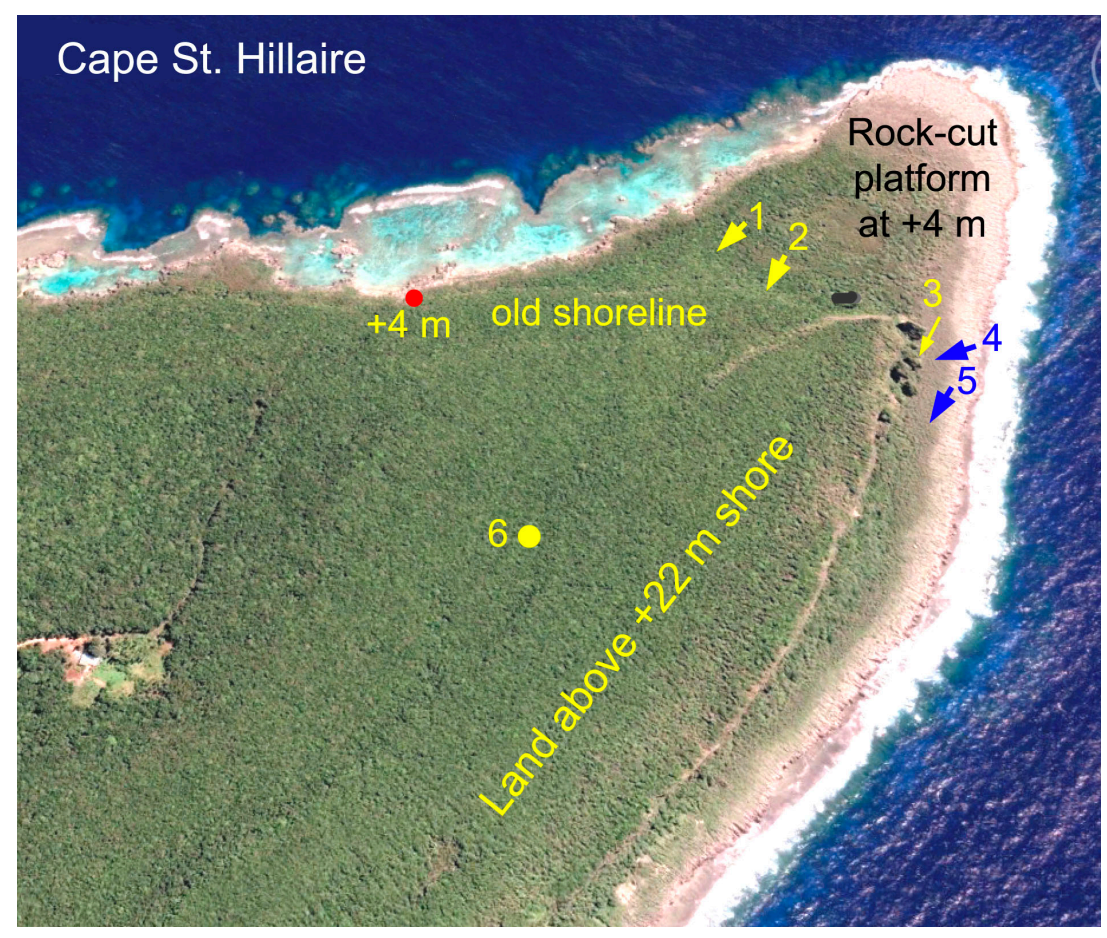

Figure 9. The Cape St. Hillaire area with a SW-NE trending ridge bounded by the $+22 \mathrm{~m}$ shoreline, an extensive rock-cut platform in the $\mathrm{NE}$ and along the eastern coast, an old shoreline in the north, at least six separate huge blocks in the NE, and six observational points ( $1-6)$ discussed in the text.

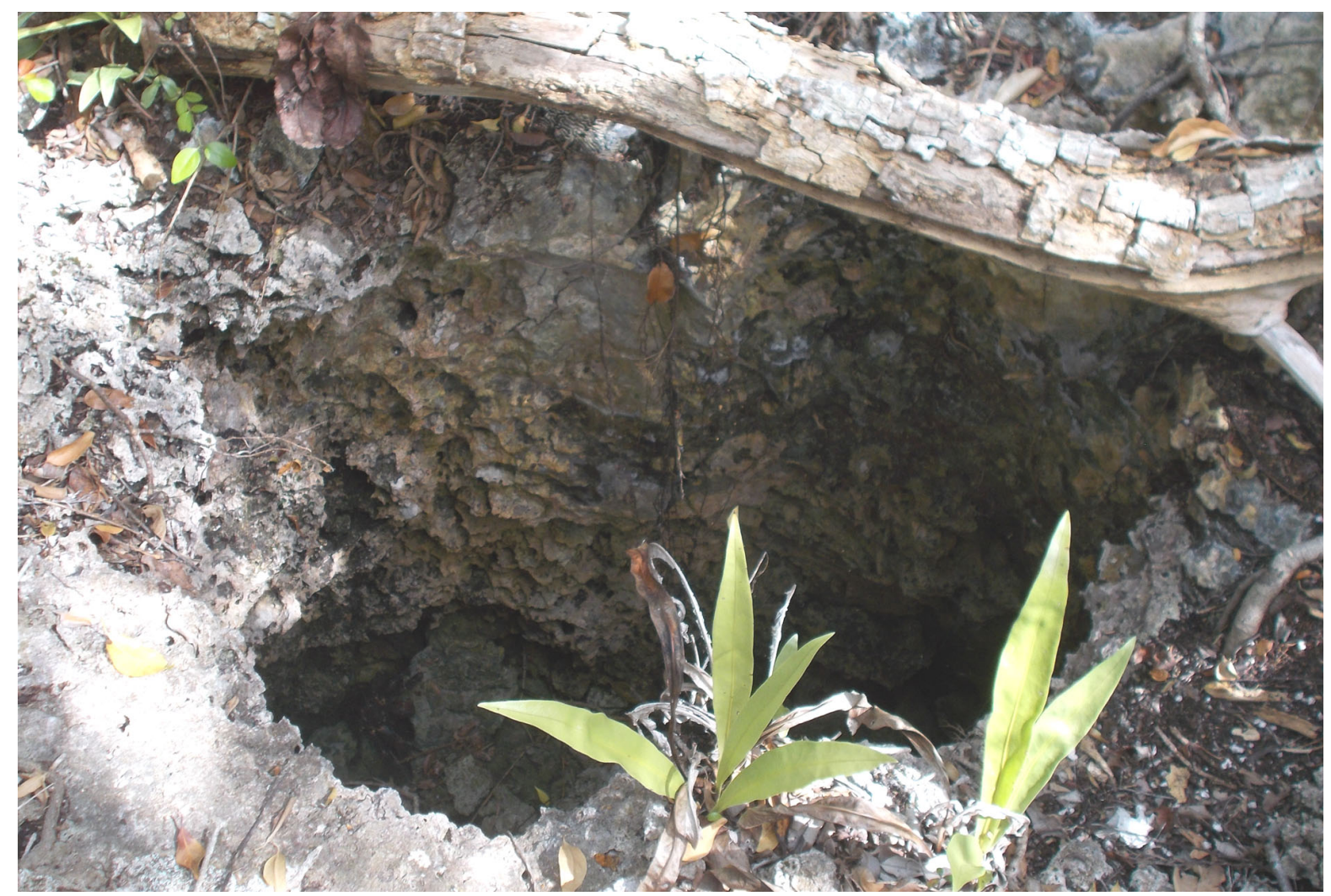

Figure 10. Karstic dissolution holes in the $+4 \mathrm{~m}$ rock-cut platform at point 1 . 


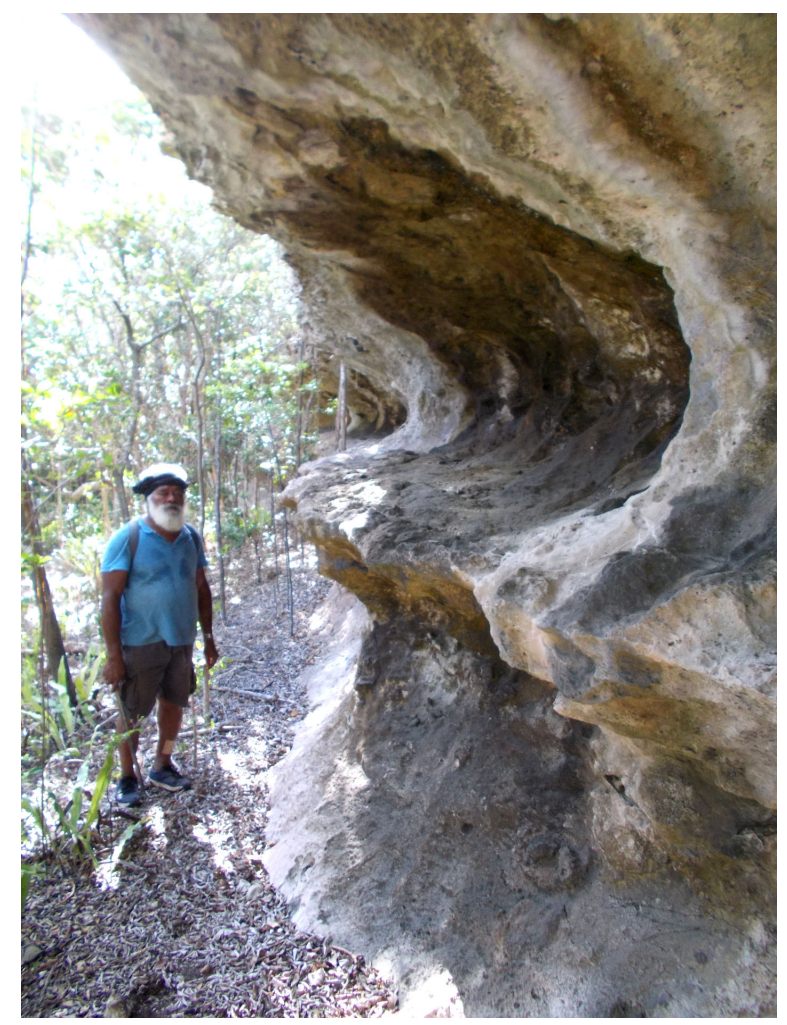

Figure 11. Double notch in the E-W old shoreline cliff at point 2 with my guide Mathius Waneux as scale. The upper notch is $2.0 \mathrm{~m}$ above the foot of the cliff (which here is sloping up above the rock-cut platform outside), and seem to correspond to the $+9 \mathrm{~m}$ notch in Figure 12 (or a sub-unit of this stage at about $+6 \mathrm{~m}$ ).

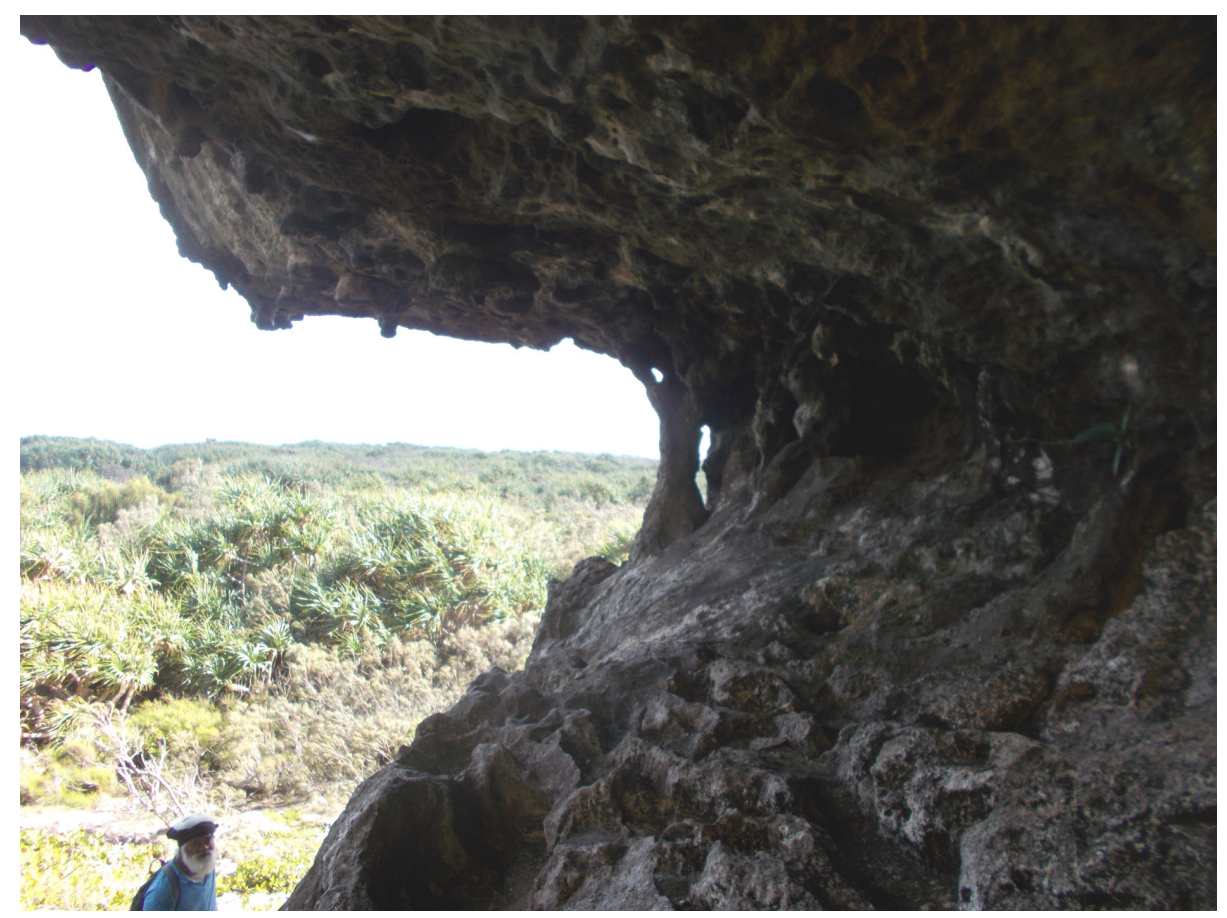

Figure 12. The $+9 \mathrm{~m}$ notch in one of the huge blocks in the NE (point 3 ). 


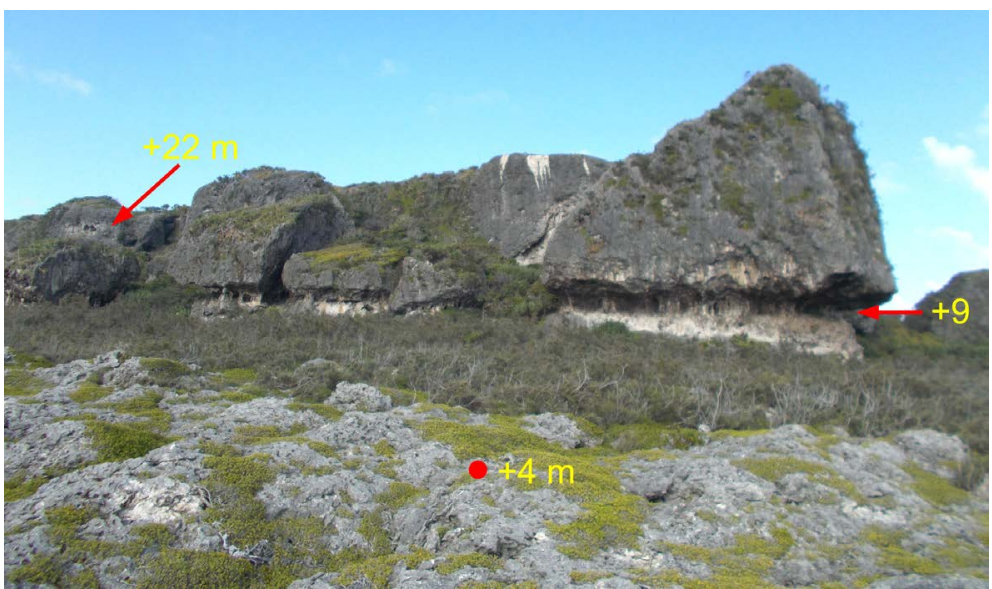

Figure 13. View of the three paleo-shores $(+4 \mathrm{~m},+9 \mathrm{~m},+22 \mathrm{~m})$ in the northeast (point 4).

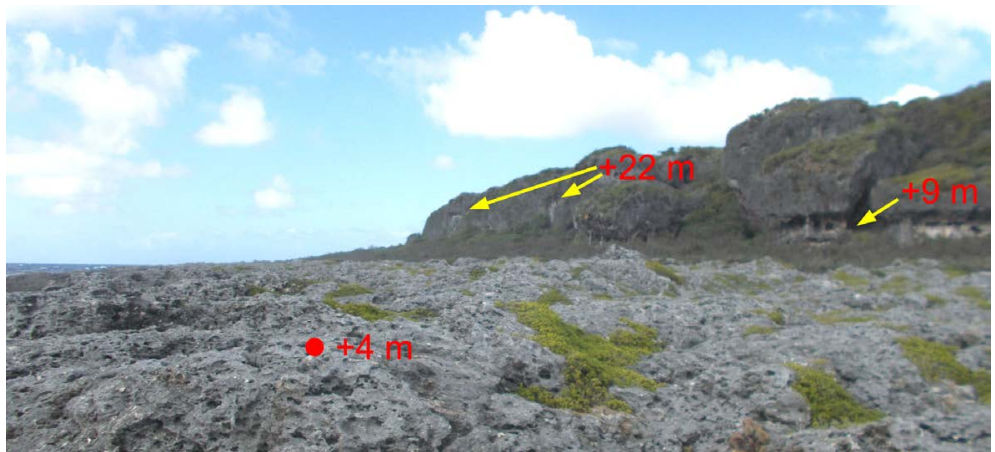

Figure 14. View southwards from point 5 showing the extensive $+4 \mathrm{~m}$ rock-cut platform, the $+9 \mathrm{~m}$ notch, and the $+22 \mathrm{~m}$ hanging paleo-shore.

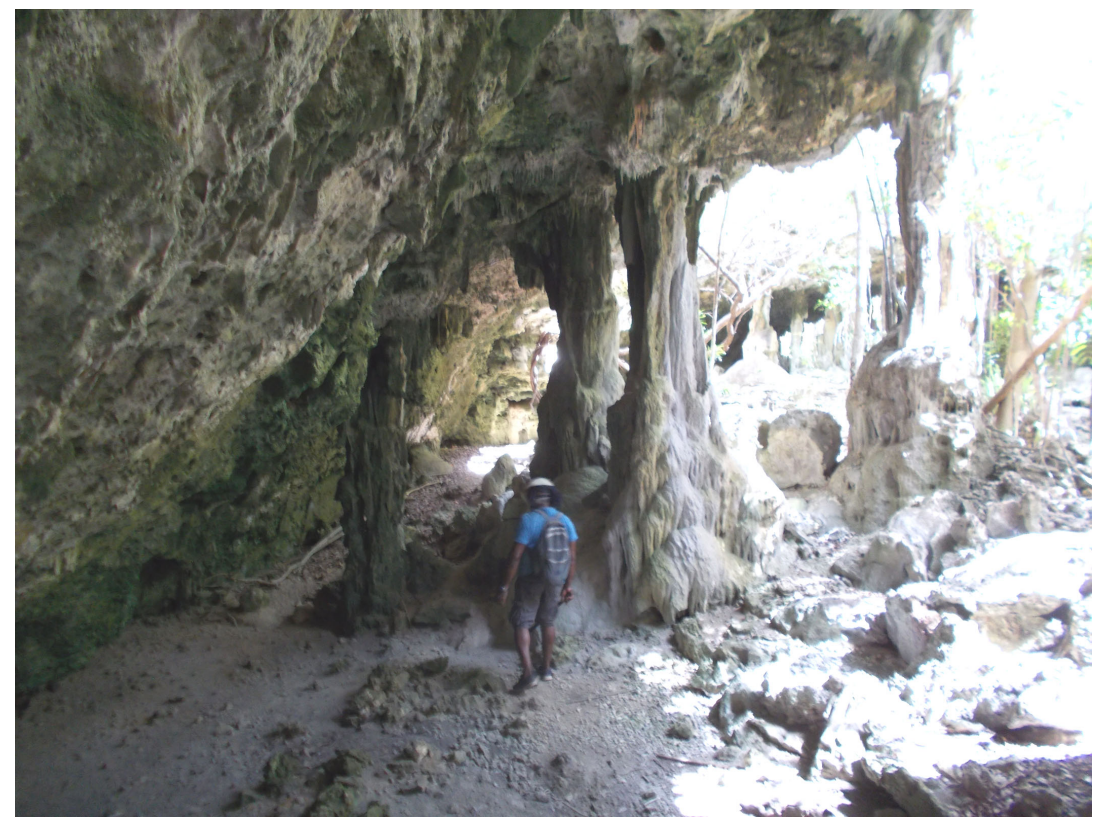

Figure 15. Part of a huge karstic cave system at around point 6, indicating an old age with a long time for dissolution and stalactite/stalagmite formation. 


\subsection{Site 12 (Col Du Casse-Cou)}

This site lies in the narrow central part of Ouvéa Island (Figure 6). There are spectacular morphological shore features of the Holocene sea levels to be discussed below (5.11). Higher up, there is a $20 \mathrm{~m}$ wide reef terrace ending in $3 \mathrm{~m}$ cliff with a basal notch at $+5.0 \mathrm{~m}$ at its foot. Above there is a $30-40 \mathrm{~m}$ wide plane rising from $+7.65 \mathrm{~m}$ to $+8.10 \mathrm{~cm}$ and ending in a $6 \mathrm{~m}$ cliff. Up in the forest there is a third paleo-shore on the order of $+20 \mathrm{~m}$.

So, we get a repetition of the of the 3 levels documented at Lekiny Cliff and St. Hillaire: a $+4-5 \mathrm{~m}$ level, a $+8-9 \mathrm{~m}$ level and $\mathrm{a}+22 \mathrm{~m}$ level.

\subsection{The Northern Highland}

The northern area is quite inaccessible preventing detailed analyses within the time at disposal. At Plaga de Tiberia (Site 9 on Figure 6), there is a paleo-shore of assumed Last Interglacial age. It is not so distinct, but still clear as representing a former sea level. It was levelled at $+5.5 \mathrm{~m}$, and seems to correlate to the extensive $+4 \mathrm{~m}$ rock-cut platforms at Sites 5 and 14 .

Between Site 9 and Weneki (St. Joseph), the road passes over an extensive wave-cut plane. Occasionally gigantic sea stacks emerge from the plane. It seems the plane is associated with the $+22 \mathrm{~m}$ shore (as recorded in Sties 5 and 14).

In the northern part of the island, there is a narrow land ridge projecting along the coast east of Teouta and up to Cape Rossel in the north (Figure 16). It is only 300 m wide and extends for $4.2 \mathrm{~km}$ on Figure 16. It is bounded by the $+22 \mathrm{~m}$ shore, and correlated with the land ridge observed at Site 14 (Figure 9).

\subsection{The Unyee Island in the Northwest}

The Unyee Island has remains of 3 separate pre-Holocene sea levels (Figure 17). In the north there are 7 flat-top remains of the $+22 \mathrm{~m}$ shore-platform bounded by cliffs of the $+8-9 \mathrm{~m}$ shore. In the south (and SW) there is a clear shoreline, corresponding to the $+4 \mathrm{~m}$ rock-cut platform in the Lekiny Cliff (Site 5) and at Cape St. Hillaire (Site 14).

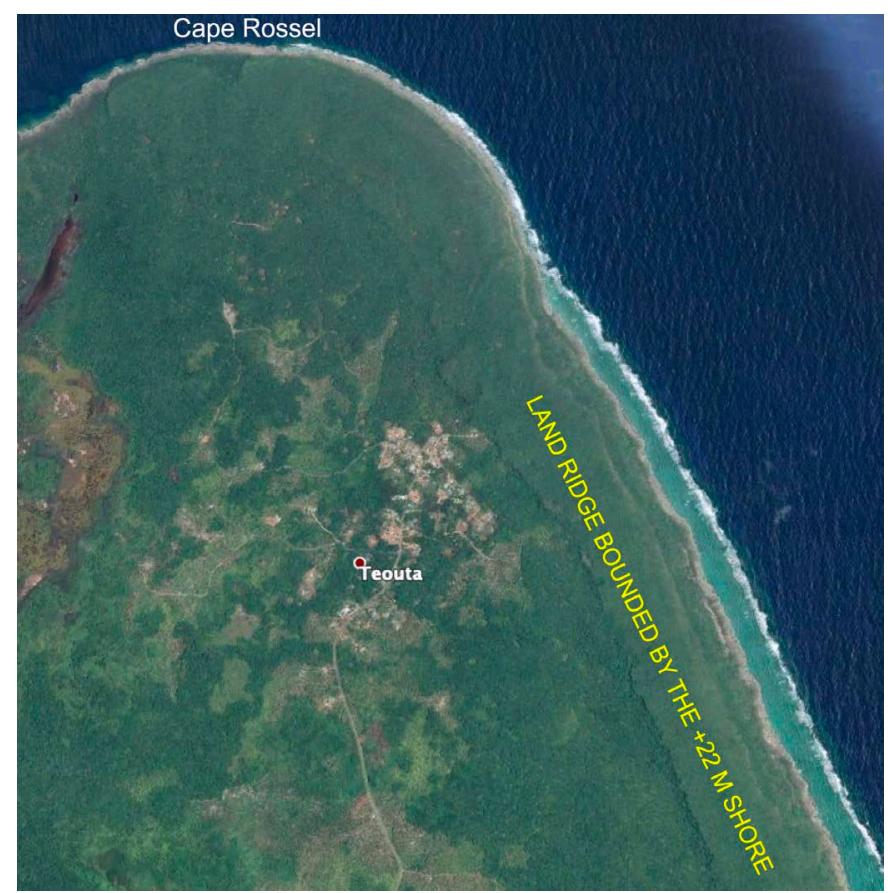

Figure 16. The northernmost part of Ouvéa Island with a narrow land ridge (300 $\mathrm{m}$ wide and $4.4 \mathrm{~km}$ long) above the $+22 \mathrm{~m}$ shore. 


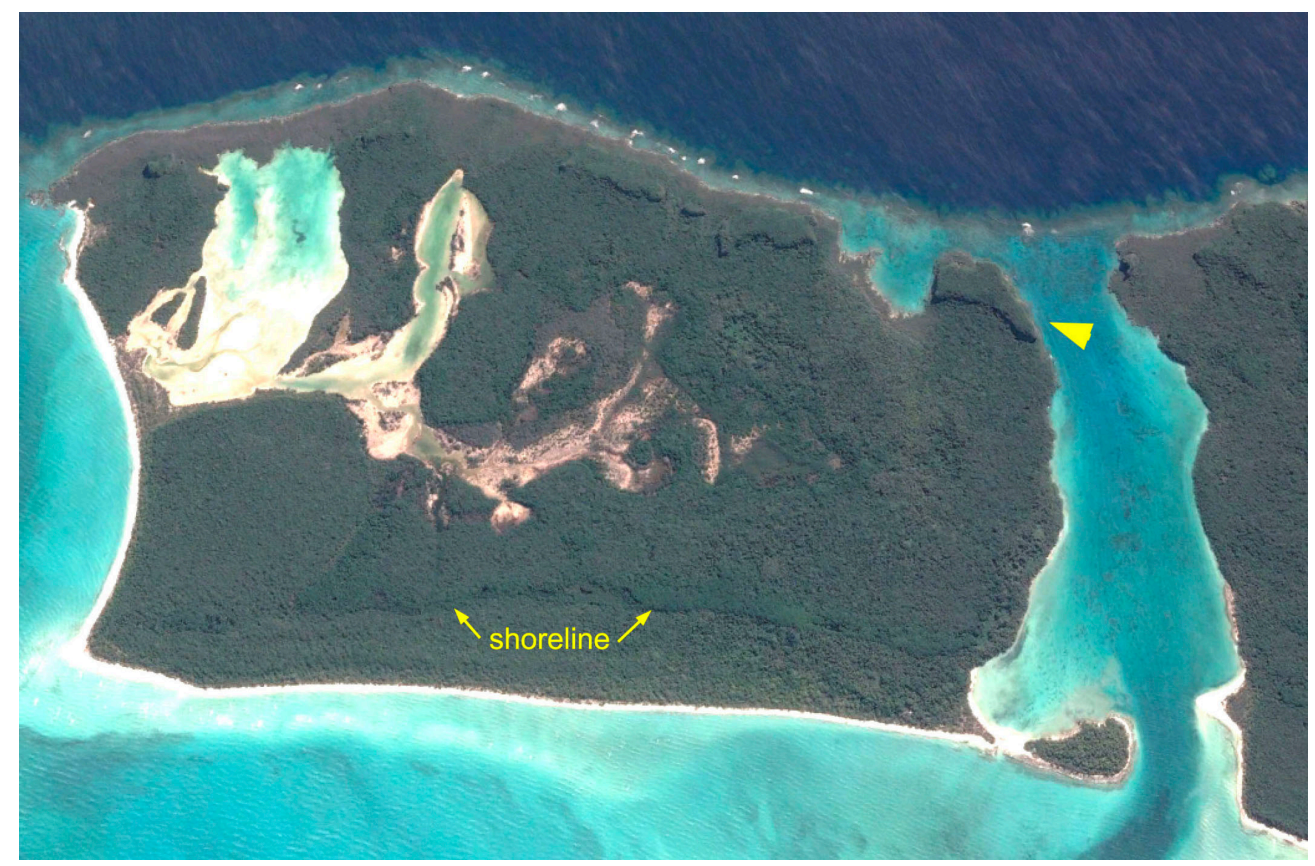

Figure 17. The Unyee Island in northwesternmost Ouvéa Island. Yellow arrow-head gives view direction of Figure 18.

The +8 - $9 \mathrm{~m}$ paleo-shore in Figure 18 is very clear. It is filled with stalactites from a subsequent period when sea level was low and precipitation was higher than today. Almost certainly this was the last Ice Age period, hence indicating that the paleo-shore dates from the Last Interglacial.

\subsection{The Southern Part of Ouvéa}

In the south, there are several sites at elevations exceeding $10-20 \mathrm{~m}$. Much of the area is private, however, and inaccessible to visitors. At Site 20, there is a distinct rock-cut terrace at about $+4 \mathrm{~m}$. Due to extensive present-day under-cut erosion on the seaward side, huge blocks have tilted-over into the sea (Figure 19).

Closer to Site 6 , the rock-cut platform has an elevation of $+3.3 \mathrm{~m}$ and extends to a shore notch at +5.9 $\mathrm{m}$ towards a higher reef level of $+7.4 \mathrm{~m}$.

\subsection{The Pre-Holocene Sea Levels: A Summary}

The Lekiny Cliff is a remarkable site documenting former sea levels: a rock-cut platform at about +4 $\mathrm{m}$ (floor of sea cave levelled at $+4.3 \mathrm{~m}$ ) in the Lekiny Cliff, a huge under-cut notch at about $+8-9 \mathrm{~m}$, and a high paleo-shore at $+22 \mathrm{~m}$. The same three levels are found at Cape St. Hilaire (Site 14). Dissolution hollows in the $+4 \mathrm{~m}$ rock-cut platform are indicative of a significant change in climate conditions following the high sea level. It seems logical to assume conditions of the Last Ice Age. At site 12, the $+4 \mathrm{~m}$ (the cliff foot was levelled at $+5.0 \mathrm{~m}$ ) and the $+8 \mathrm{~m}$ shores are separated and clearly successive; the lower following the higher. This is also the case on Unyee Island in the north (Figure 18). It seems likely to assume a Last Interglacial age of both levels; probably stage $5 \mathrm{e}$ for the $+8-9 \mathrm{~m}$ shore and stage $5 \mathrm{a}$ for the $+4-5 \mathrm{~m}$ shore.

The $+22 \mathrm{~m}$ shore seems to be significantly older, judging from the character of the shore, and the deep karstic cave weathering at point 6 at Cape St. Hillaire (Figure 15).

\section{RESULTS: THE HOLOCENE, SUB-RECENT AND PRESENT SEA LEVELS}

There are no morphological remains of a Holocene maximum shore level in the key sections of 


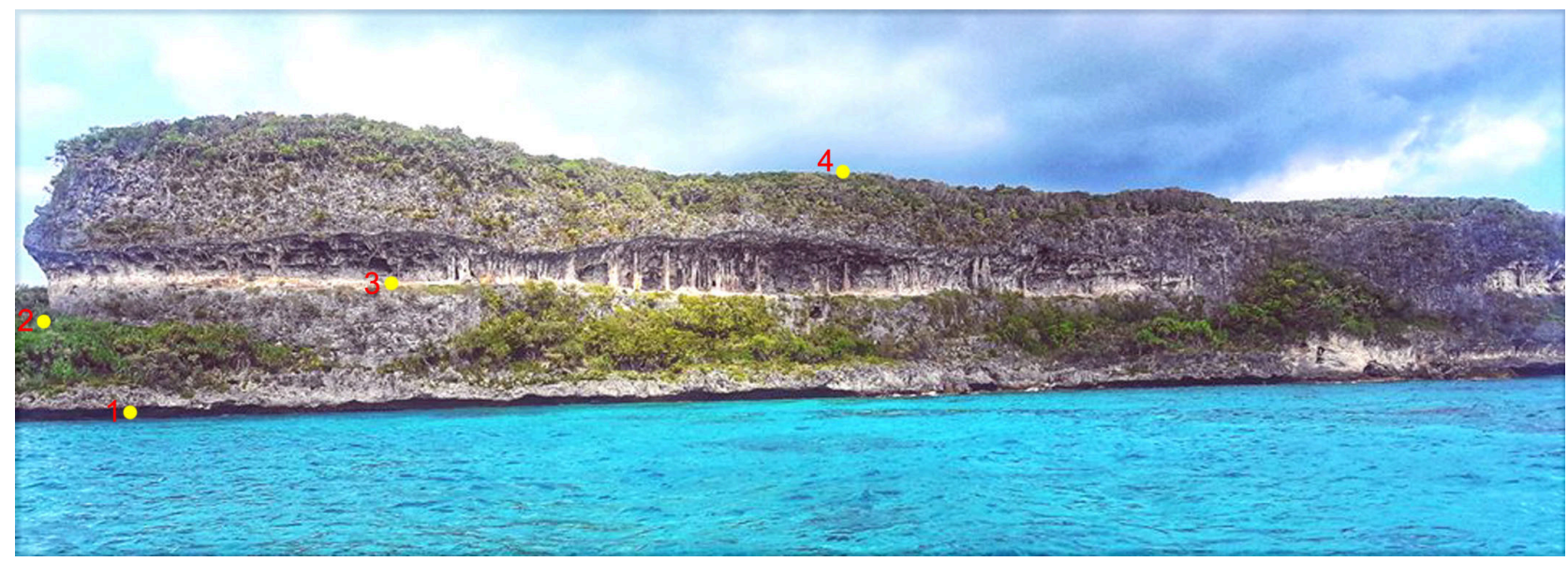

Figure 18. View of the reef hill in the NE of Unyee Island. (1) present HTL undercut notch, (2) the $+4-5 \mathrm{~m}$ cliff foot, (3) the extensive paleo-shore at $+8-9 \mathrm{~m}$ with later stalactites, and (4) the $+22 \mathrm{~m}$ shore plane surface. Foto: Pierre Thomas Wachou.

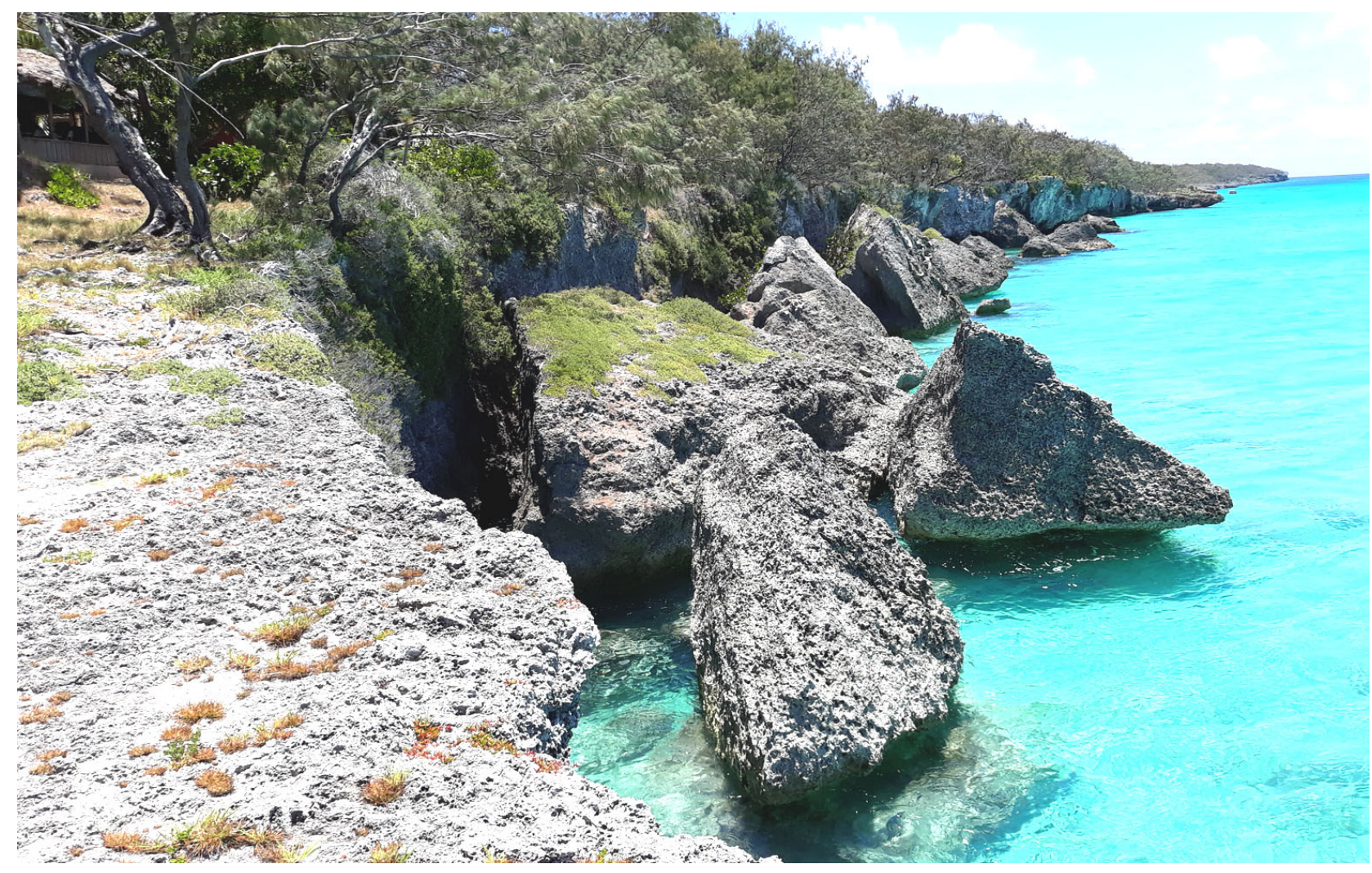

Figure 19. A distinct rock-cut platform gives a quite horizontal reef-surface. Due to present-day shore under-cut, huge blocks have fractured-off and fallen out into the sea.

Lekiny Cliff and at Cape St. Hillaire. But there are records elsewhere. The present shore is well expressed by extensive under-cut notches at HTL. About $70 \mathrm{~cm}$ above the HTL, there are multiple records of a fresh shore or rock-cut terrace that must be of sub-recent age. We explore the records from the south to the north. 


\subsection{Site 1, the Southern Tio of Ouvéa Island}

This site was repeatedly investigated, both at low tide and high tide. The main elements and shore characteristics are shown in Figure 20.

The $+70 \mathrm{~cm}$ rock-cut platform is well recorded at several different parts of the site. The surface is flat and only weakly affected by weathering. The platform in bounded by clear erosional boundary marks and minor under-cuts and cave hollows (Figure 21). The elevation was fixed at $70 \mathrm{~cm}$ above present HTL (Figure 20).

There is a quite clear older shore level on the order of $+2 \mathrm{~m}$ (Figure 22). This surface is strongly weathered, and must be significantly older than the $+70 \mathrm{~cm}$ shore. It is covered by loose shells and corals. In the innermost part of the $+2 \mathrm{~m}$ plane, shells were collected and C14-dated at $111.8 \pm 04 \% \mathrm{MC}$, i.e. a post-1950 age. Obviously the shells were deposited at a big storm in recent time.

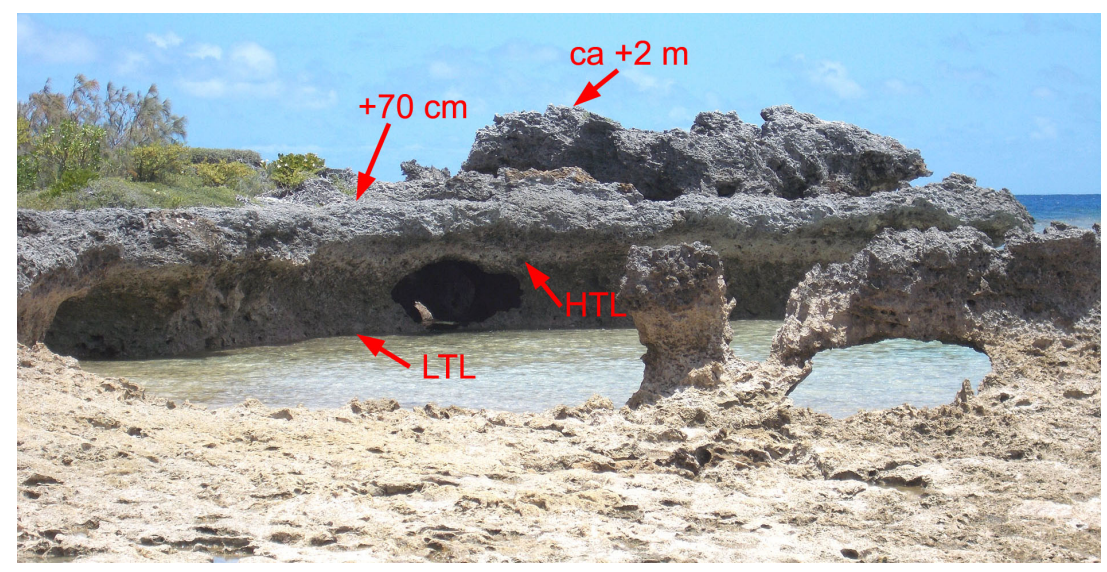

Figure 20. Site 1 at low tide. The low tide (LTL) corresponds to the base of two shore caves. The high tide level (HTL) corresponds to the roofs of the caves and a distinct under-cut notch. There is a flat rock-cut platform of sub-recent weathering character. There is also an irregular and very strongly weathered surface at about +1.5 to $2 \mathrm{~m}$.

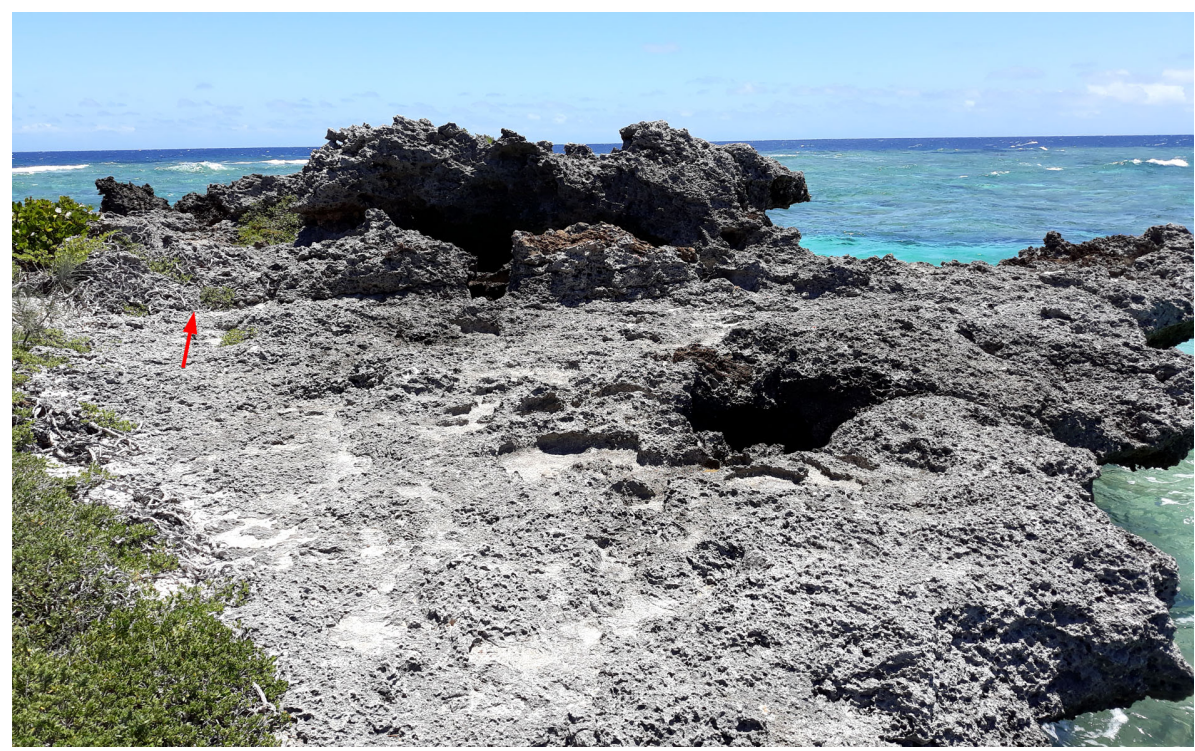

Figure 21 . The $+70 \mathrm{~cm}$ rock-cut platform with erosion edge marked with a red arrow. The surface is fresh and hardly weathered indicating a young (sub-recent) age. 


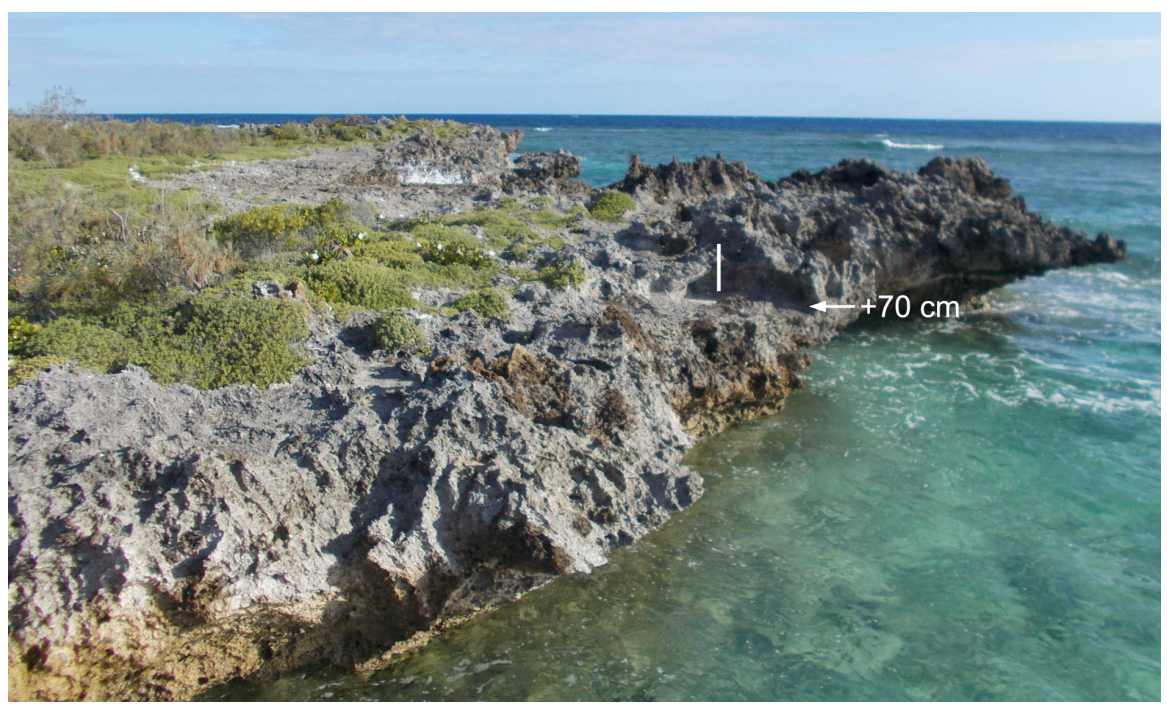

Figure 22. The strongly weathered maximum Holocene sea level, partly covered by young storm material of shells and corals. The inner edge of the platform was levelled at $+1.9 \mathrm{~m}$. Shells from the innermost part of the littoral cover were C14-dated as younger than 1950, which means that recent extreme storms reaches $1.5 \mathrm{~m}$, or more, above present HTL The white rod, placed in a small engulfment of the $+70 \mathrm{~cm}$ plane, is $1 \mathrm{~m}$ long.

In a profile levelled from the shore inlands, there are two reef notches, one at $+70 \mathrm{~cm}$ and one at +190 $\mathrm{cm}$. The upper one must mark the Holocene maximum sea level (and there are no traces of any higher potential Holocene levels). The $+70 \mathrm{~cm}$ level is so fresh that it cannot be very old. Therefore, a "sub-recent" age was assumed (i.e. an age from the last centuries).

\subsection{Site 6}

This is an important site for the temporal and morphological linkage of the present sea level and that of the $+70 \mathrm{~cm}$ stage [9]. The present sandy shore ends at a vertical cliff in the old reef complex. The height was levelled at $+2.5 \mathrm{~m}$ above present HTL. The top is flat and seems to be an extension of the $+4 \mathrm{~m}$ rock-cut platform (Section 4). Neither in the cliff surface nor on top of the $+2.5 \mathrm{~m}$ surface, there are any traces of a Holocene high sea level. This is consistent with the observation at Site 1, where a notch was found at $+1.9 \mathrm{~m}$.

At the foot of the cliff there is a line of sea caves. Today they are all inactive and filled with sand. There elevation is $70 \mathrm{~cm}$ above the present HTL (Figure 23). Genetically they must be closely related to the present shore. The assumed age of this $+70 \mathrm{~cm}$ sea level position is therefore given as "sub-recent", i.e. from the last centuries or last half a millennium.

In Figure 24, there are two sea cave generations; an upper stage extending in the $+70 \mathrm{~cm}$ erosion line, and a lower stage, now inactive and filled with sand (probably from an earlier phase of the present sea level stage, when the long-shore sand transportation had not yet built the present wide sandy shore).

\subsection{Sites 16 and 15 (the Northern Shore of Mouli)}

Sites 16 and 15 have quite similar shore profiles (Figure 25). The present shore is a broad and flat sandy beach. In both profiles, "the washing limit" (WL) is marked by an erosional scarp of 60 (a) to 80 (b) $\mathrm{cm}$ height. On these sandy shores, the HTL is hard to fix with precision. This may be the reason why the levelled heights in the two profiles differ by $20 \mathrm{~cm}$. Whilst the WL-notch is still active in Site 15 (b), it seems nearly abounded in Site 16 (a), indicating that present sea level, at least, is not in a rising mode today [1]. 


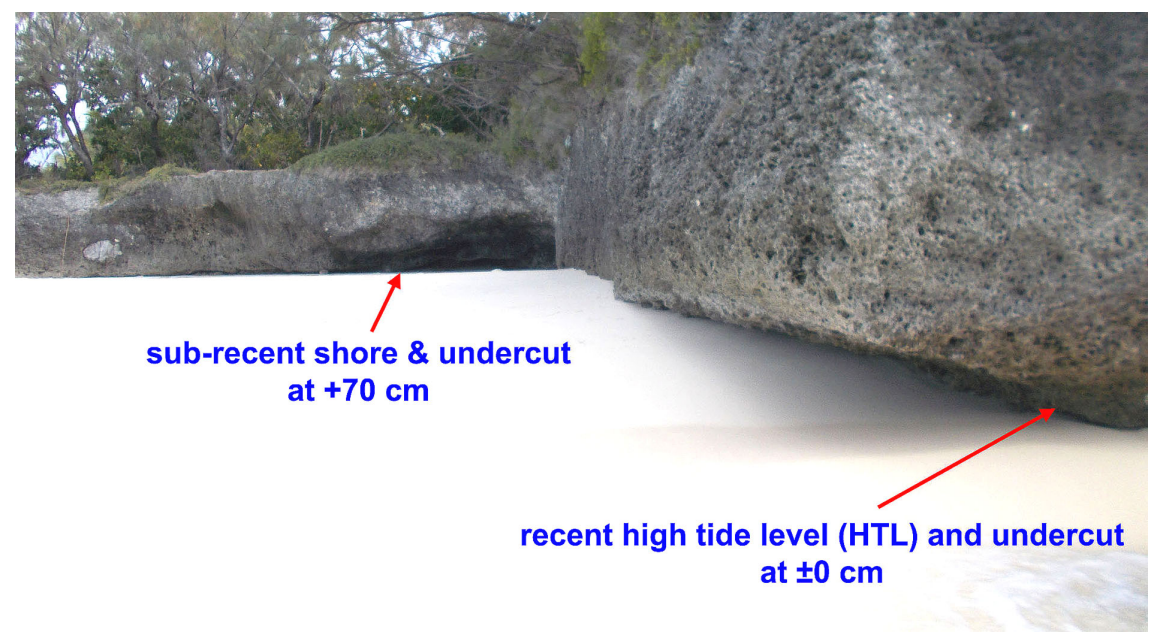

Figure 23. The present sandy shore ends at a cliff in the old reef reaching $+2.5 \mathrm{~m}$. There are two separate beach stages recorded along the shore; the present one with a clear under-cut notch at present HTL (our \pm 0.0 level), and an abandoned (now inactive) shore with large sea caves at the cliff foot at $+70 \mathrm{~cm}$ (the sub-recent shore).

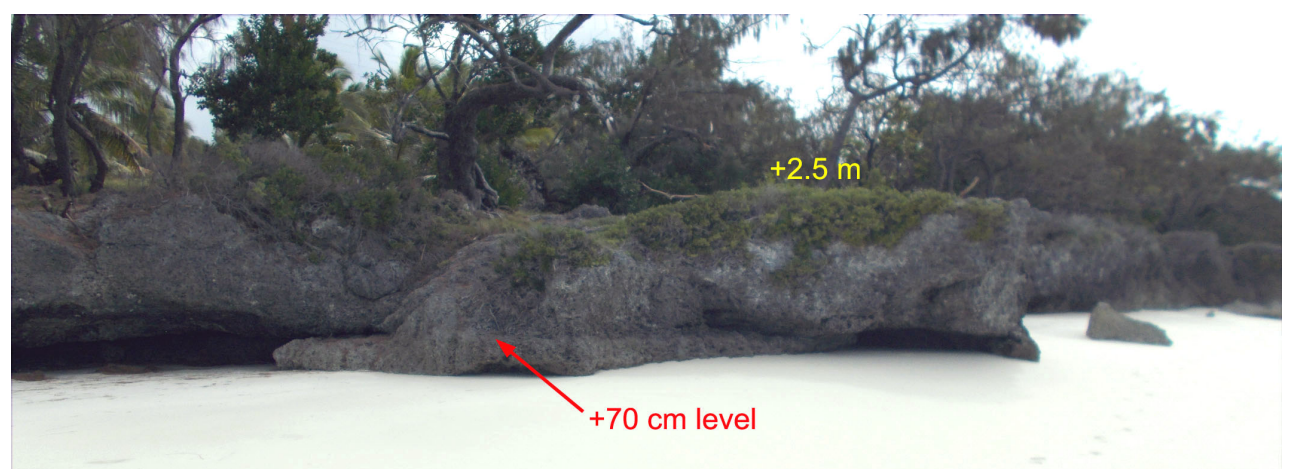

Figure 24. Erosional mark of the $+70 \mathrm{~cm}$ sea level extending into an upper sea cave stage.
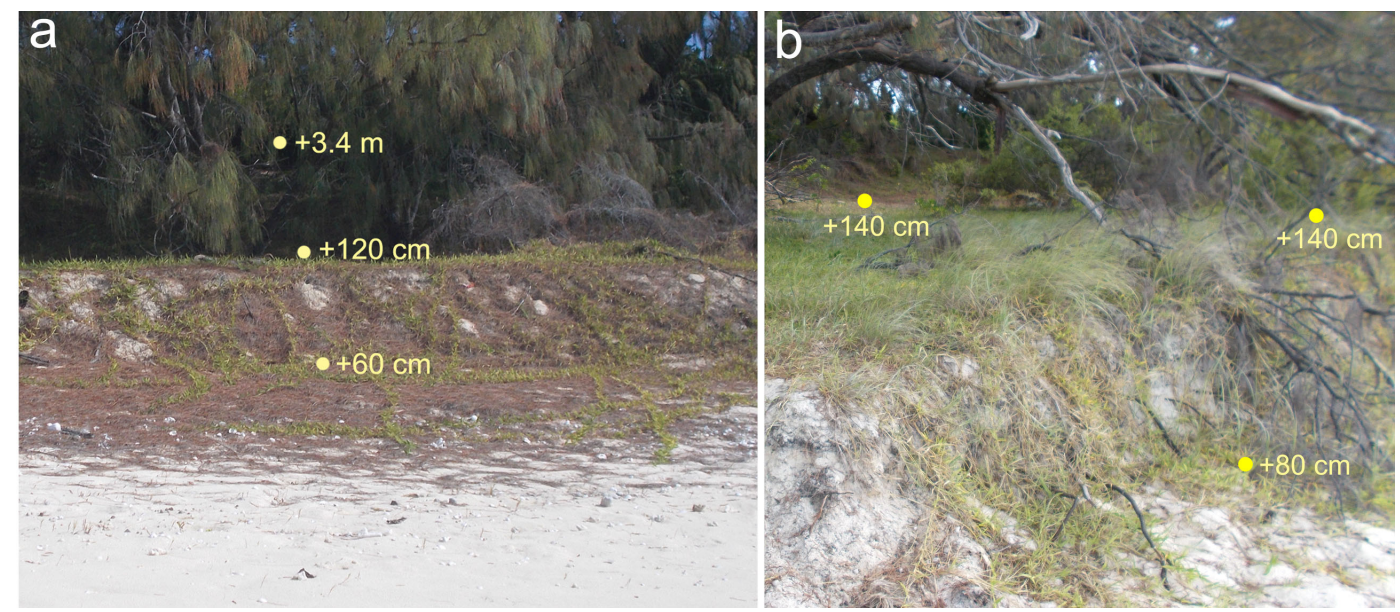

Figure 25. Sites 16 (a) and 15 (b) both have a tri-part shore profile: (1) a present washing limit ending in a 60 (a) to 80 (b) steep slope, (2) a terrace at $+120 \mathrm{~cm}$ (a) and $140 \mathrm{~cm}$ (b) ending in steep slopes, and (3) a sand ridge reaching with its crest at $+3.4 \mathrm{~m}$. 
The second stage is a sandy terrace at $+120 \mathrm{~cm}$ (a) and $+140 \mathrm{~cm}$ (b), both ending in a steep slope inland. Both terraces seem young and of sub-recent age. It seems reasonable to assume that they represent remains of the washing limit associated to the $+70 \mathrm{~cm}$ shore documented in the nearby Site 6 .

The sandy slope inside rises to a ridge with its crest at $+3.4 \mathrm{~m}$. This is assumed to be a coastal sand-bar of a Holocene sea level optimum with a HTL at about $+1.5-1.9 \mathrm{~m}$ (Site 1) but not reaching +2.5 m (Site 6).

\subsection{Site 3 (Lekiny Camp Site and Surroundings)}

The Mouli bridge (built in 1984) connects the sandy shore of Lekiny and the sandy shore of Mouli. The shores towards Lekiny Bay, both at Mouli and at Lekiny Camp site, show a present HTL and washing limit (WL) ending in a now over-grown rise to a low ridge and inner plane at $70 \mathrm{~cm}$ above present washing limit (Figure 26). This must be the remains of a higher sea level in sub-recent time at about $+70 \mathrm{~cm}$ (as documented in previous sites, and as will be confirmed at later sites discussed below).

\subsection{Site 4 (Lekiny Crossing Point)}

This is the point of crossing over the Lekiny Bay estuary entrance to Lekiny Cliff. This is also the point from where the Lekiny Cliff section was levelled with a Bosch levelling instrument (Figure 7).

The shore morphology is the same as in so many other sites described: a HTL level with a higher washing limit ending at the foot of a rise to an over-grown flat $70 \mathrm{~cm}$ higher (Figure 27).

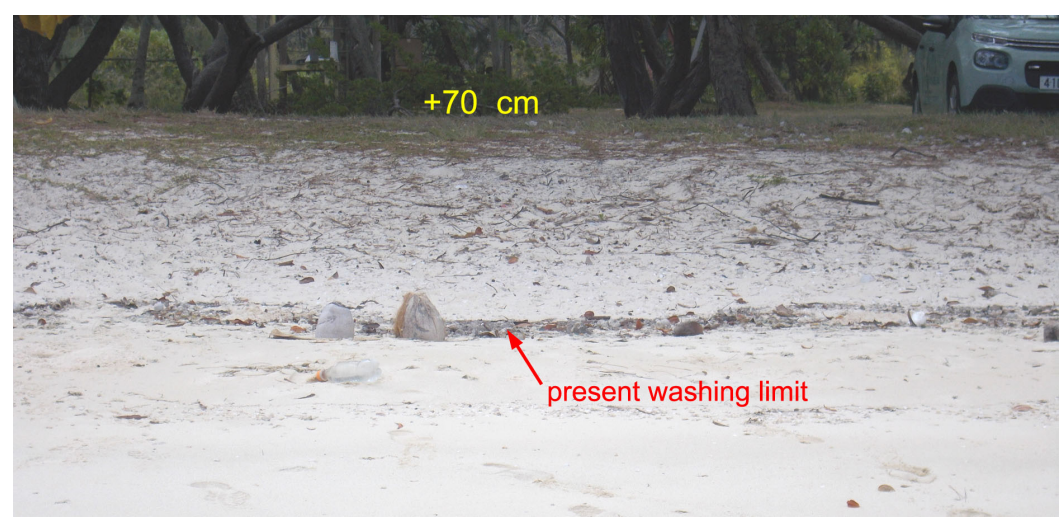

Figure 26. The shore at Lekiny Camp site. The present washing limit with a rise to an over-grown, 70 $\mathrm{cm}$ higher sand-flat, marking a higher sea level in sub-recent time.

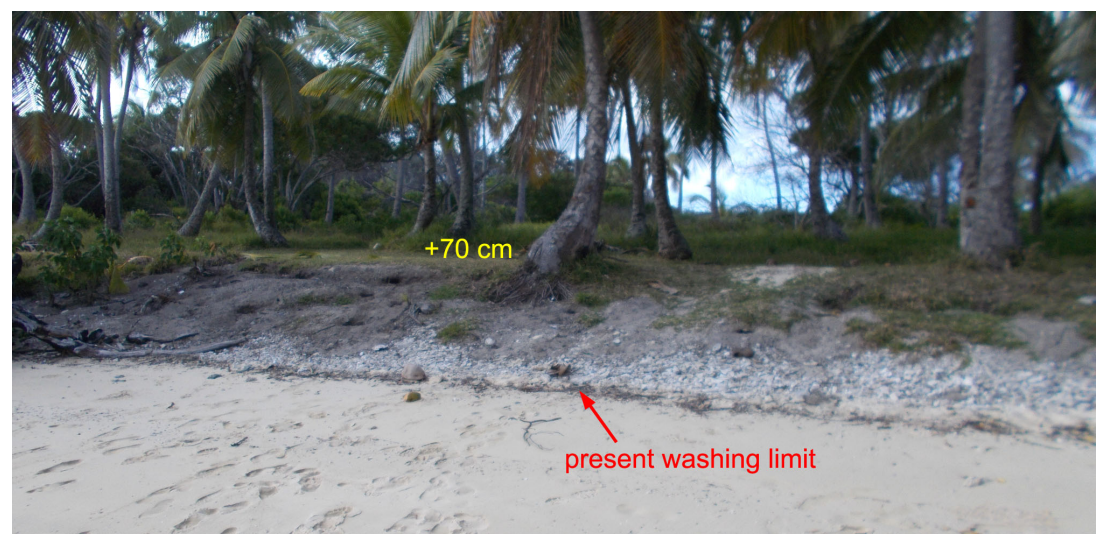

Figure 27. The shore at Site 4 showing a present beach ending at the present washing limit with a slope up to a $+70 \mathrm{~cm}$ higher shore surface of sub-recent age. 


\subsection{Site 7 (the Lekiny Bay Estuary)}

To the northeast of Site 4, there is a shallow estuary reaching $3-4 \mathrm{~km}$ inland (Figure 28), which we hereby term "the Lekiny Bay estuary".

Large parts of the former open estuary are now in the stage of becoming over-grown (Figure 29). This confirms that local sea level is presently not in a rising mode but rather in a stable to falling mode, as first proposed in 2018 [1, 9].

At point 4, there is estuarine mud with open sea molluscs from a sub-recent stage of open water conditions. This is further expressed in the occurrence of a paleo-shore notch at an elevation of $+70 \mathrm{~cm}$ (Figure 30). This indicates the occurrence of a $+70 \mathrm{~cm}$ higher sea level with open sea conditions in the present estuary in sub-recent time.

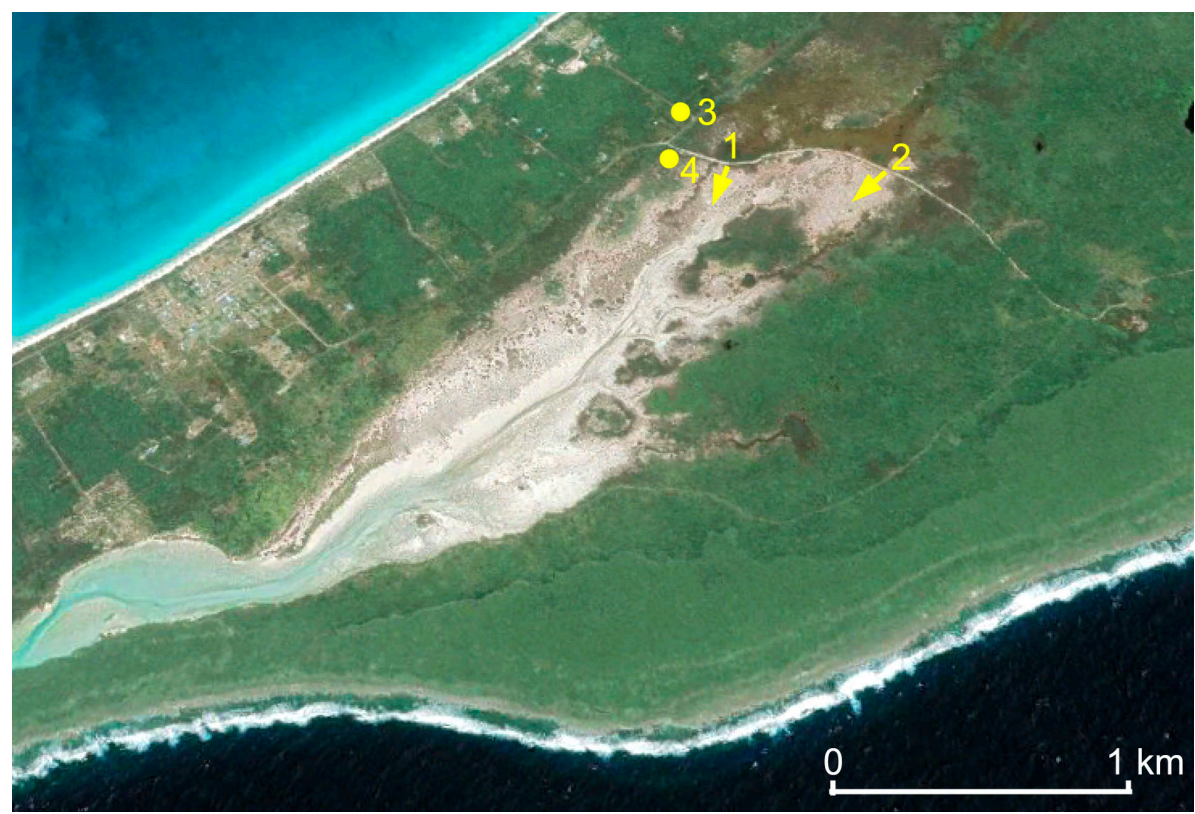

Figure 28. The Lekiny Bay estuary reaching $3-4 \mathrm{~km}$ inland and becoming progressively more over-grown inland. It provides clear observational facts that sea level is not in a rising mode in this part of the world, on the contrary it seems to be stable or even falling a little. Points $1-4$ are further discussed in the text.

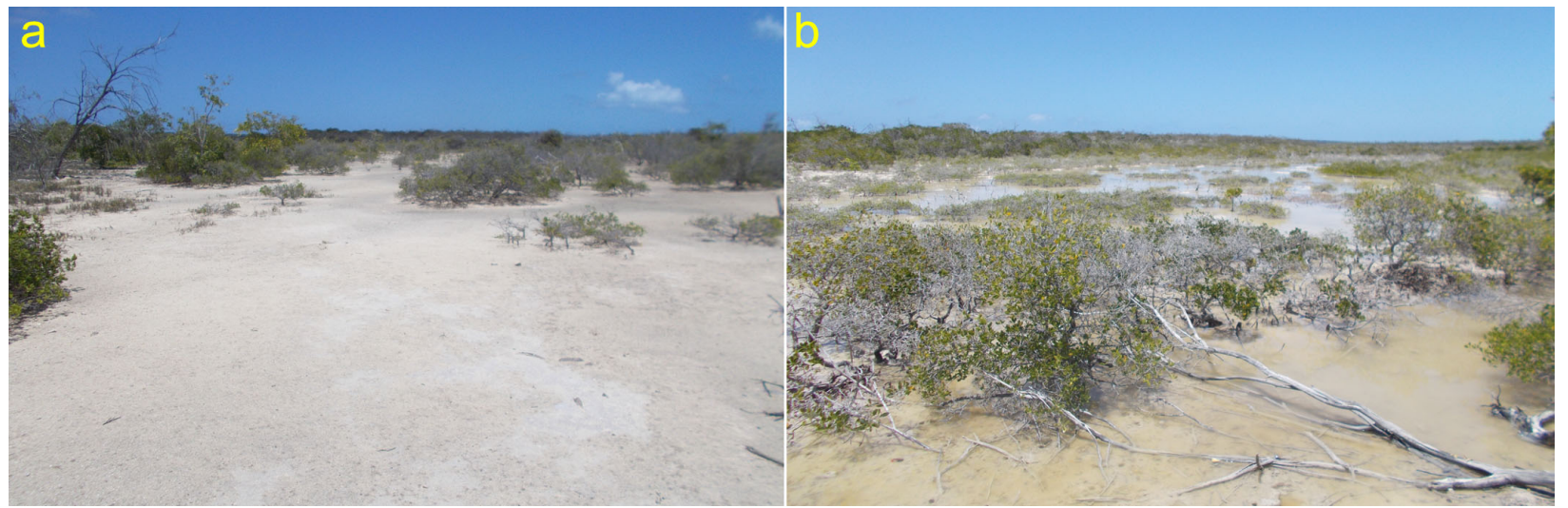

Figure 29. Views over the inner part of the estuary from point 1 (b) and 2 (a) illustrating the ongoing process of shallowing and over-growing. 


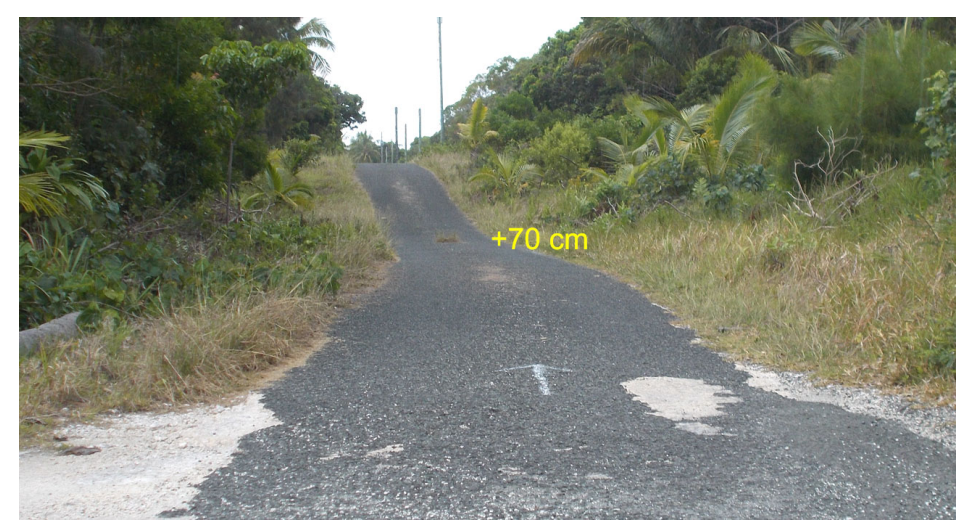

Figure 30. A shore mark from a former sea level at about $+70 \mathrm{~cm}$. Estuarine mud with a molluscan fauna of open marine conditions occurs $175 \mathrm{~m}$ to the south (point 4).

\subsection{Site 5 (the Lekiny Cliff)}

Figure 31 gives the setting of the cliff section, in total extending over $2.5 \mathrm{~km}$. Views of the section were also obtained from Sites 3 and 4 . Access to the section was from Site 4.

This is our key section (4.1) also with respect to present and sub-recent changes in sea level [1,9]. The Lekiny Cliff is a remarkable archive of late Quaternary sea level changes. In this section, we will investigate the present and sub-recent records of sea level changes (cf. [1,9]).

Although the Last Interglacial shore (complex and probably formed by multiple isotopic stage 5 high sea level stands) is of significantly larger dimensions (Figure 32), the present under-cut notch is impressive, too (Figure 33). As to the present shore notch, there are two fundamental observations to note, viz.:

- There are no traces what so ever of any Mid to Late Holocene sea level high-stand.

- The under-cut shore ends in a double shore notch; an abandoned bench and an active zone at present

HTL (Figure 34 and Figure 35).

The original notch ends in a $20 \mathrm{~cm}$ flat horizontal bench at the former high-tide level (Figure 36). This level is now inactive and located $70 \mathrm{~cm}$ above the present HTL, where active under-cut erosion and shore cave formation occur (Figure 35). Full evidence of the present abandoning of the upper shore bench is demonstrated by the fact that stalactites were found in the hanging roof above with an irregular stalagmite precipitation on the bench surface below (Figure 36), indicating a formation under sub-aerial conditions.

In the sea off the SW point of the cliff (Figure 31), there are numerous minor coral groups (Figure 37). They are flat instead of rounded, because of too shallow water depth, forcing them to grow only laterally as micro-atolls. This implies that sea level is not at all in a rising mode, but stable or maybe even falling a little.

In conclusion, this site tells us: 1) that there is an absence of traces of any Holocene high sea level, 2) that there is a now abandoned notch and sea level bench at $+70 \mathrm{~cm}$, which has stalactites in the roof and stalagmite precipitation on the former sea level bench, 3) that active erosion occurs at present HTL, and 4) that corals growing as micro-atolls indicate that present sea level is not rising rather stable or even falling $[1]$.

\subsection{Site 13}

The shore profile is very similar to those in Sites 15 and 16, viz. a sandy beach ending in a washing limit at the foot of a $40 \mathrm{~cm}$ notch $(+80 \mathrm{~cm}$ over the HTL) rising to an about $10 \mathrm{~m}$ wide terrace at $+120 \mathrm{~cm}$, ending at a slope rising into a ridge with its crest at $+3.6 \mathrm{~m}$.

The $+120 \mathrm{~cm}$ terrace is likely to represent the washing zone of the $+70 \mathrm{~cm}$ sub-recent sea level high. The ridge seems older and is interpreted as a coastal sand-ridge of the Holocene maximum sea level at about $+1.5 \mathrm{~m}$, or somewhat higher. 


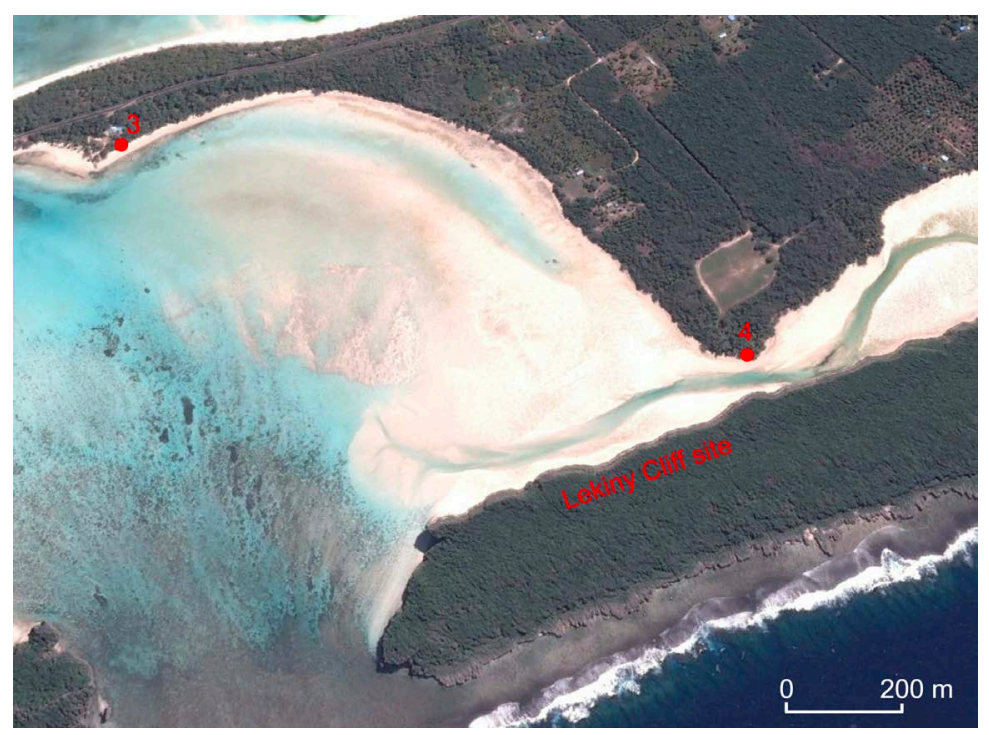

Figure 31. Geographic location of the Lekiny Cliff section.
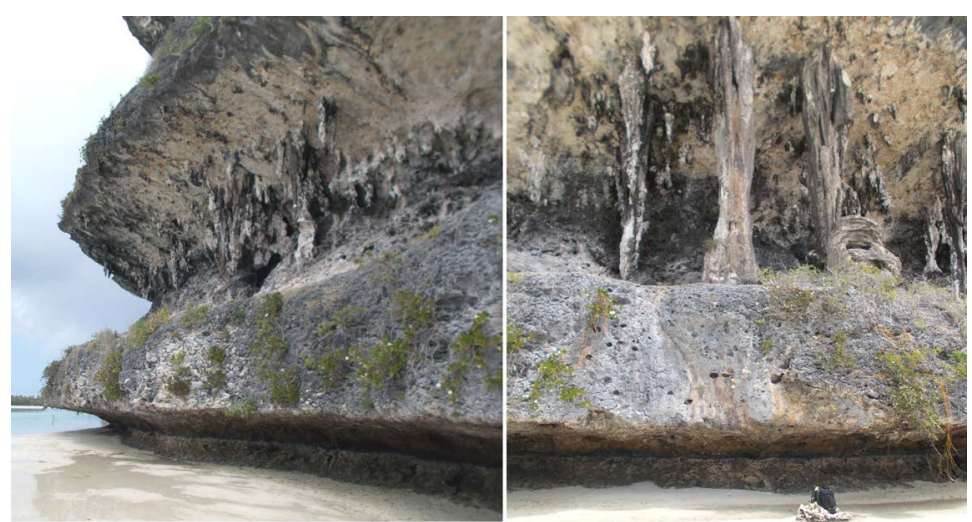

Figure 32. Comparison between the Last Interglacial mega shore-notch and the present under-cut notch.

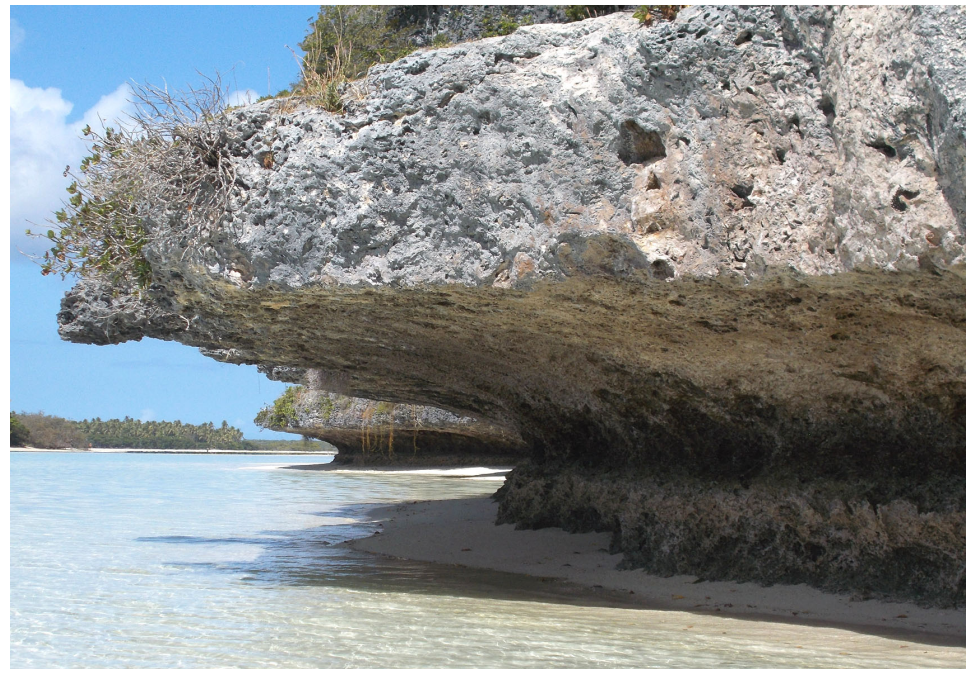

Figure 33. The present under-cut notch is quite impressive, too. 


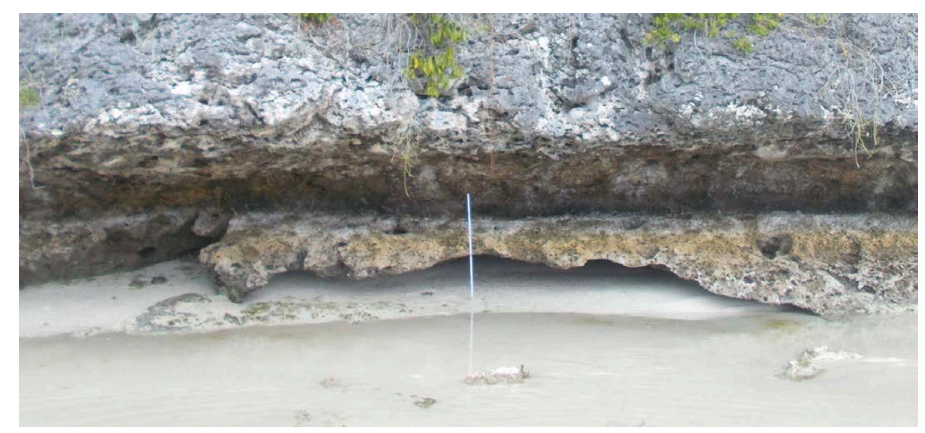

Figure 34. The present under-cut notch ends in a horizontal bench located $70 \mathrm{~cm}$ above the presently active under-cut and cave erosion at HTL.

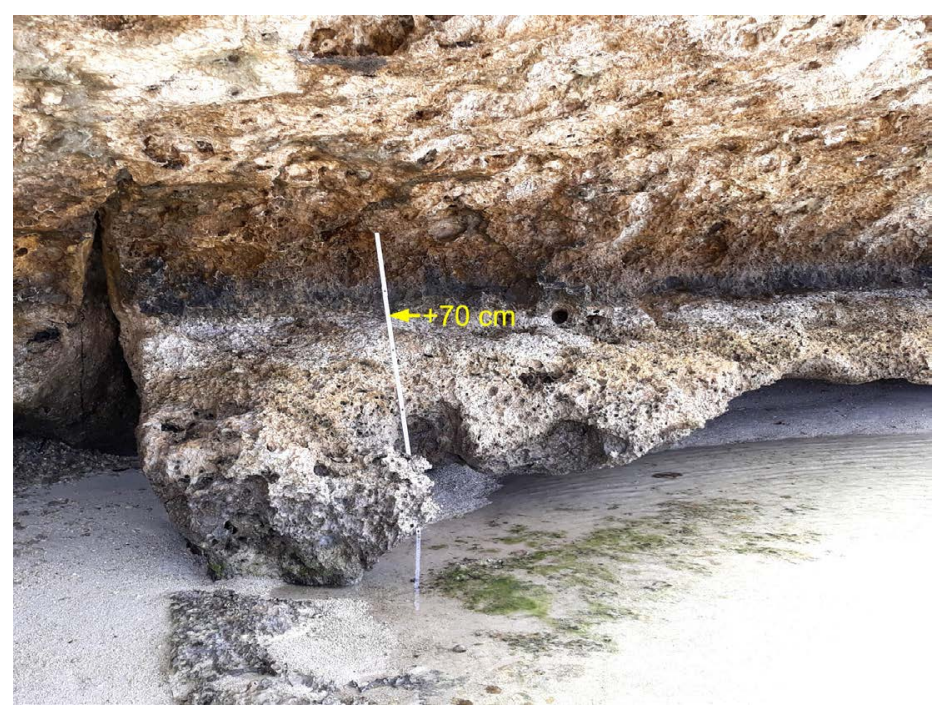

Figure 35. Close-up of the under-cut notch morphology: an abandoned shore bench at $+70 \mathrm{~cm}$ and the presently active under-cut erosion at HTL.

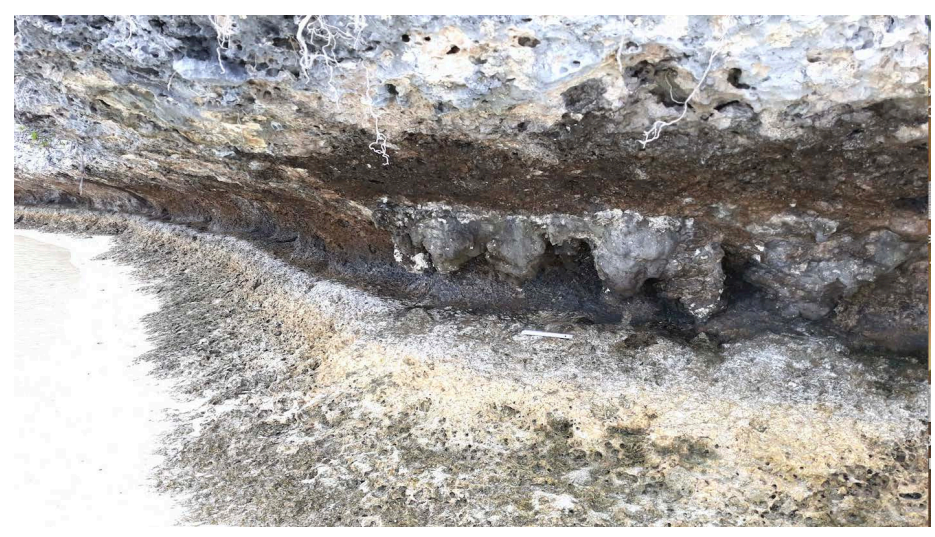

Figure 36. The horizontal bench at the extremity of the under-cut notch with 5 - 6 stalactites (in the right hand roof) and with stalagmite precipitation on the bench below (erasing the original bench form here). Stalactite/stalagmite formation is indicative of sub-aerial climatic conditions; i.e. a location above the sea level. The size of the stalactites suggests a time of formation on the order of centuries. 


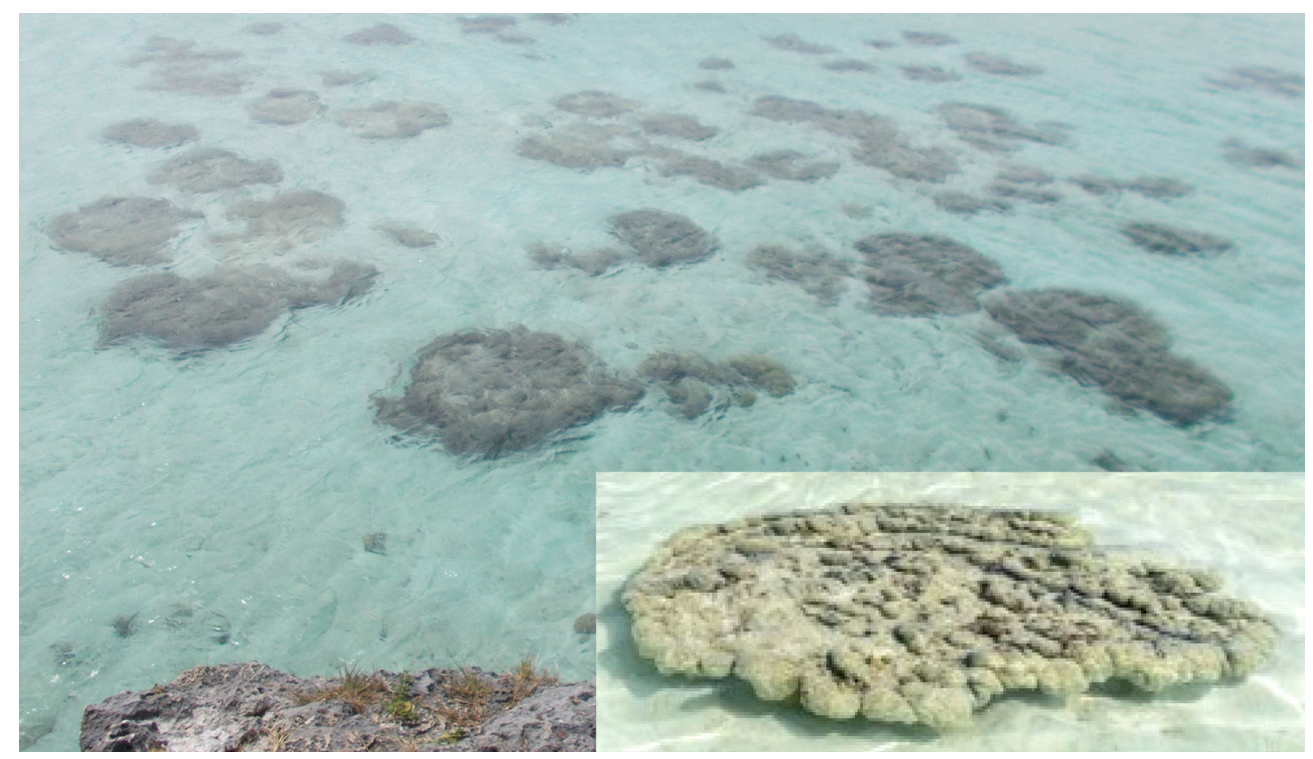

Figure 37. Corals forced to grow laterally as micro-atolls due to too shallow water depth.

\subsection{Site 17 (Hanaawa)}

This site exhibits an unusually clear former sea level cut into the old reef as an extensive rock-cut platform. Because of its freshness and lack of weathering, it must represent a shore level of young age; i.e. a $+70 \mathrm{~cm}$ sea level position in sub-recent time $[2,9]$.

The site records the occurrence of two separate former sea levels (Figure 38 and Figure 39). The lower platform is extensive and of a young appearance, being fresh and lacking signs of weathering. Therefore, it is assigned a sub-recent age [9]. A thick molluscan shell cemented in the surface was C14dated. The age was $>40,000$ years, which means that it is an erosional relic from the reef itself. It indicates, however, that the coastal reefs, into which the two shore platforms are cut, are of a high age; i.e. Last Interglacial or older.

\subsection{Site 12}

This site, facing the open ocean in the east, has a distinctive under-cut notch linked to present HTL. Above, there is a prominent fossil shore platform (Figure 40). The elevation is about $70-80 \mathrm{~cm}$ above present HTL. It has a low degree of weathering, and seems to have been active quite recently. Therefore, it seems highly likely that it is contemporaneous to the distinct $+70 \mathrm{~cm}$ shore in Site 17 .

There are no visible traces of a higher Mid Holocene sea level stage (as recorded in Site 17 at $+1.5 \mathrm{~m}$ ).

\subsection{Site 11}

This site records a present reef under-cut notch at HTL, and higher reef-cut plane at $+70 \mathrm{~cm}$ (just as in Sites 17 and 12).

\subsection{Sites 9 and 10}

At Site 9, there are double under-cut notches; one at about HTL and one about $100 \mathrm{~cm}$ higher. There is also a broad beach with washing limit about $+100 \mathrm{~cm}$ with a $90 \mathrm{~cm}$ rise to a higher sand terrace (Figure 41). In this sand terrace a soil has developed, indicating a time of formation on the order of hundreds of years.

At Site 10 there are double sea caves; one set at HTL and another about $100 \mathrm{~cm}$ above. Both sites face the open ocean, implying strong coastal dynamic forces. 


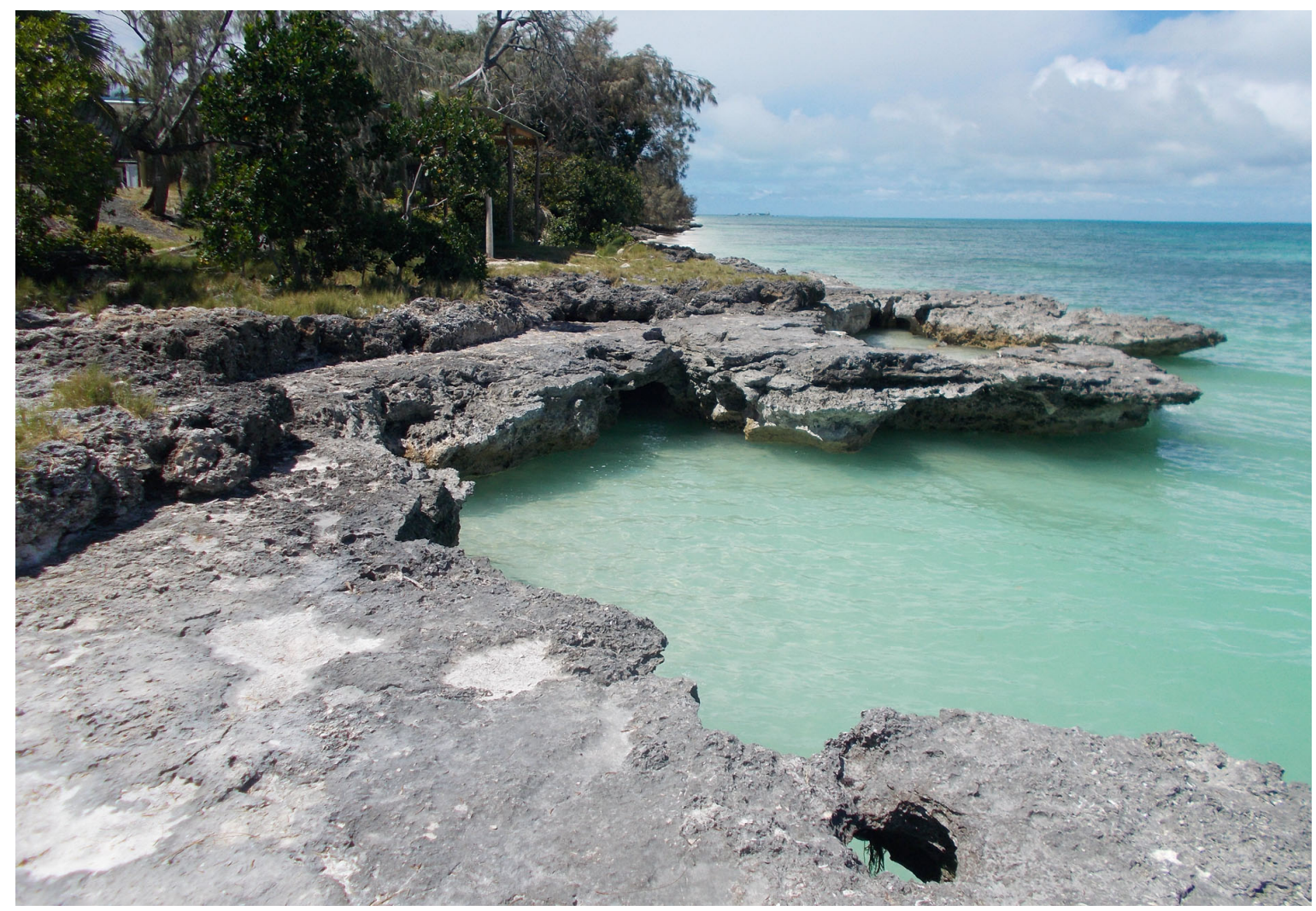

Figure 38. A fresh and un-weathered rock-cut platform at $+70 \mathrm{~cm}$ (above present HTL) and an old and strongly weathered rock-cut platform at $+1.5 \mathrm{~m}$.

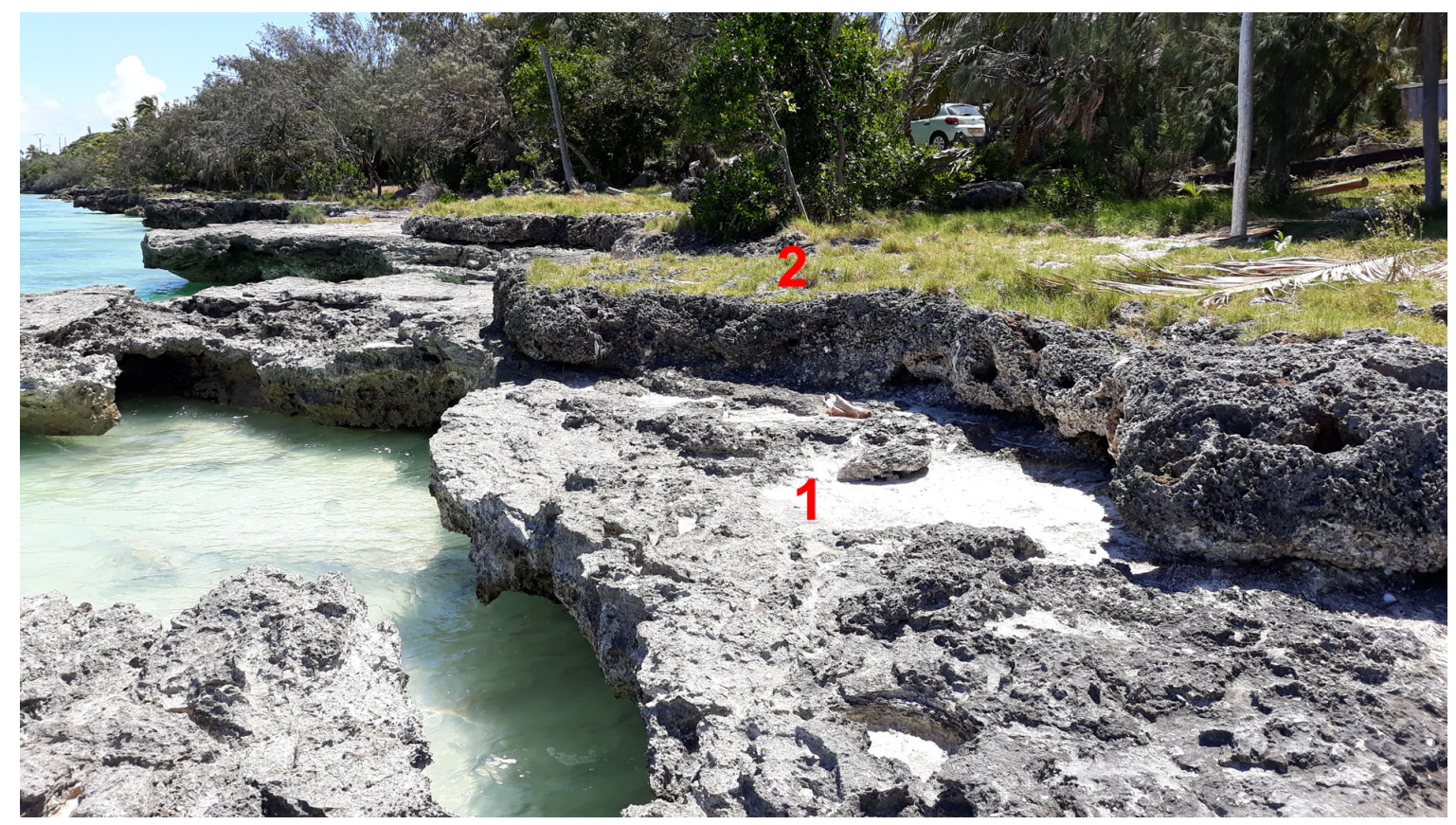

Figure 39. Two rock-cut platforms from former sea levels: (1) a young and fresh erosion surface at $+70 \mathrm{~cm}$ of sub-recent age, and (2) an old and strongly weathered surface at $+1.5 \mathrm{~m}$ of probable Mid Holocene age. 


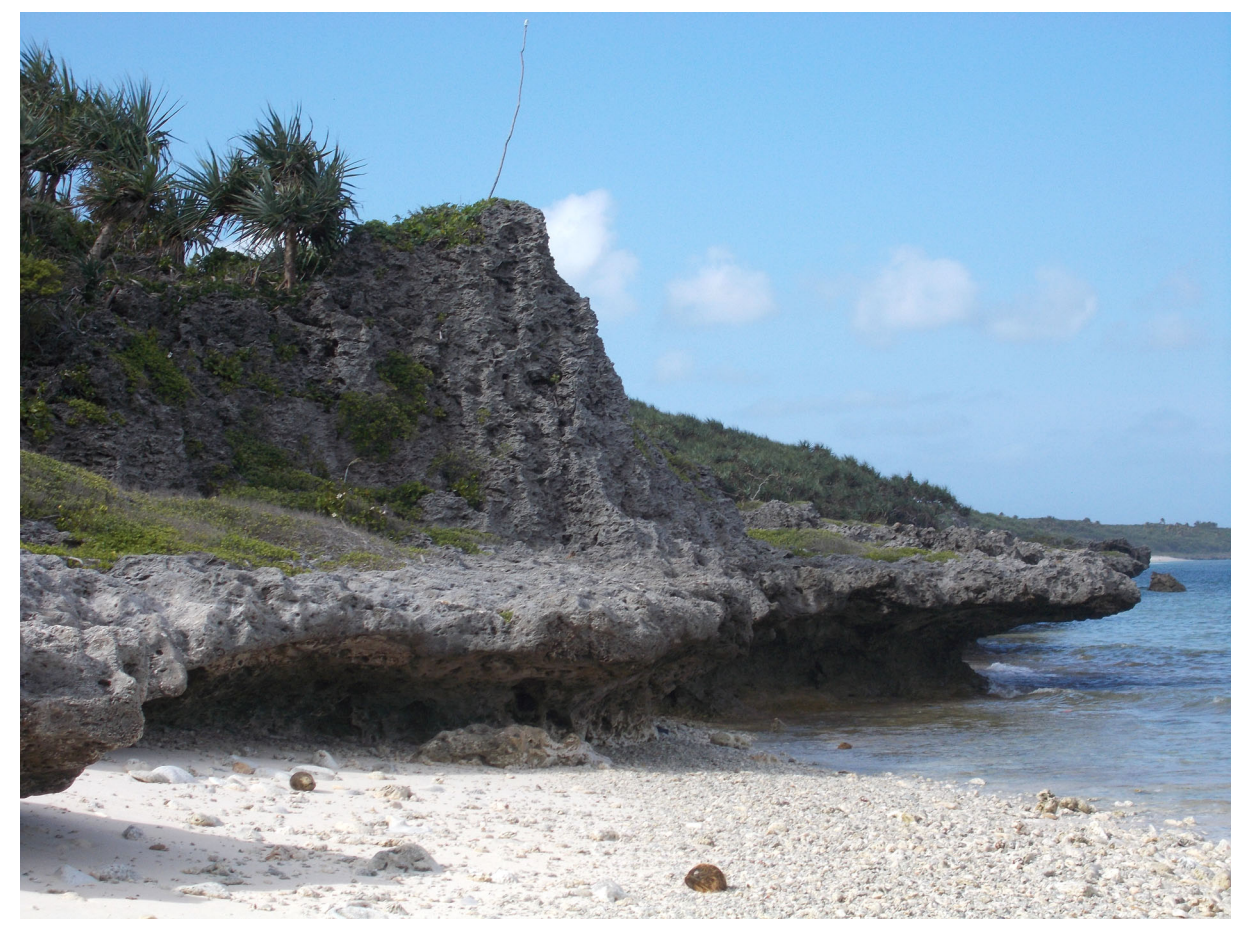

Figure 40. The present under-cut notch at HTL and a very distinct shore-cut platform above at about $+70-80 \mathrm{~cm}$ (above HTL). It is quite moderately weathered and is most likely to correlate to the +70 $\mathrm{cm}$ terrace in Site 17 [9].

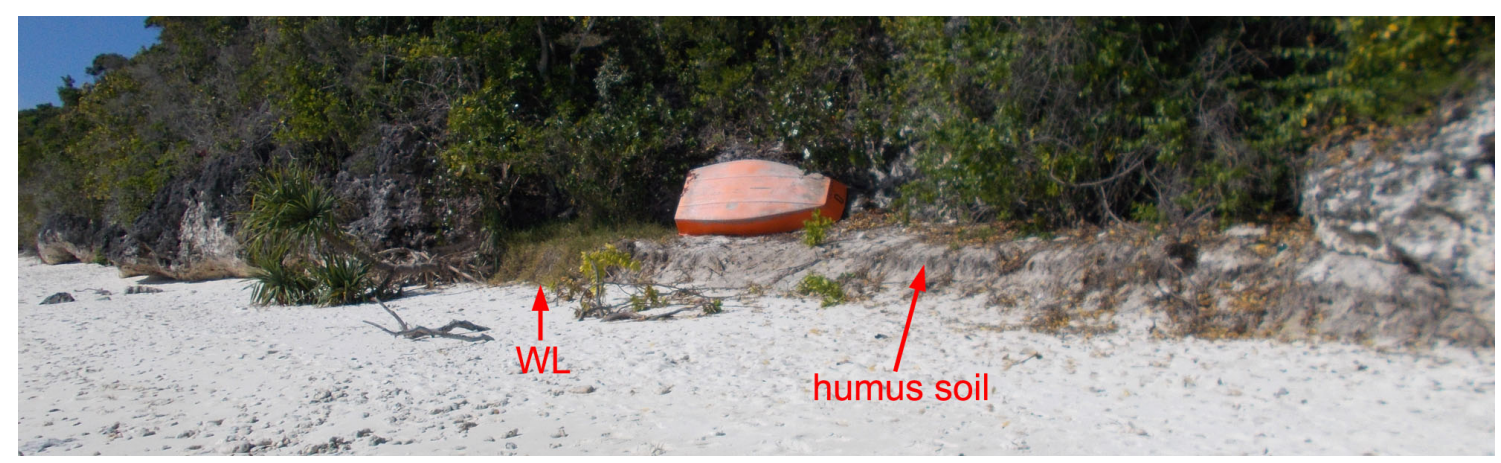

Figure 41. Site 9 upper beach with washing limit (WL) against a $90 \mathrm{~cm}$ scarp to an older sand terrace, which has a $20 \mathrm{~cm}$ humus soil in its surface (dark line at arrow).

\subsection{Sites 8 and 18 (St. Joseph Shore)}

The character of the shores of Saint-Joseph Bay differs considerably with segments of erosion, stability and accretion (illustration by Matthew Le Duff in [10]). In the 1960s it was said, the shore was much wider [10], and a postcard from the 1970s shows a somewhat wider beach. The wider shore segments 50 years ago (also claimed by an old man for the Fayaoue shore) might be the effect of a recent rise in sea level (not recorded in shore morphology and coral growth, however), but it might as well be the function of coastal dynamics [11], redistributing the sand masses along the shore and generating alternations between shore segments in erosion and in accretion (just as observed).

The coastal area $1.5 \mathrm{~km}$ to the northwest of St. Joseph is subjected to erosion (Figure 42). Because the washing limit remains intact, the erosion seems to have been induced by a severe storm hitting just at this coastal segment. 
Further to the northwest (some 2 - $3 \mathrm{~km}$ from St. Joseph) the coastal situation is quite normal (Figure 43). A HTL was identified on the shore with an active washing limit (well identifiable in Figure 43) at +60 $\mathrm{cm}$, a continuation of the washing zone, which is not wave washed for the moment, up to $+70 \mathrm{~cm}$, where a fresh sand slope rises $60 \mathrm{~cm}$ up to a second over-grown shore plane at $+130 \mathrm{~cm}$ ending at a sand slope going up to $+2.5 \mathrm{~m}$. The second shore must be the remains of a washing zone at the $+70 \mathrm{~cm}$ shore stage of sub-recent age.

Still some $700 \mathrm{~m}$ to the NW, the shore has developed in a most interesting way (Figure 44). There is a double washing limit: the one marked by active shore processes, and another in the mode of starting to become over-grown (a $2 \mathrm{~m}$ wide zone $+5-10 \mathrm{~cm}$ above the active one). The notch at the second washing limit is about $40 \mathrm{~cm}$ high.

When this figure was first published [1], it was claimed that it "provides a spectacular evidence of the absence of a present sea level rise. Anyone can with his/her own eyes see that sea is not rising on the coast of Ouvéa Island in New Caledonia". The new shore zone added (i.e. the zone no longer in the active washing zone, and in the process of becoming over-grown) is well documented in the Google Earth image of 2016 [9] indicating a formation over, at least, two years. Furthermore, it extends over a distance of about $2 \mathrm{~km}$ (judging from the Google Earth image of 2016, and my field work in 2018).

Figure 45 gives the situation another $700 \mathrm{~m}$ to the NW: an active and an over-grown washing zone, a $60 \mathrm{~cm}$ scarp, and an over-grown sub-recent shore at about $+70 \mathrm{~cm}$.

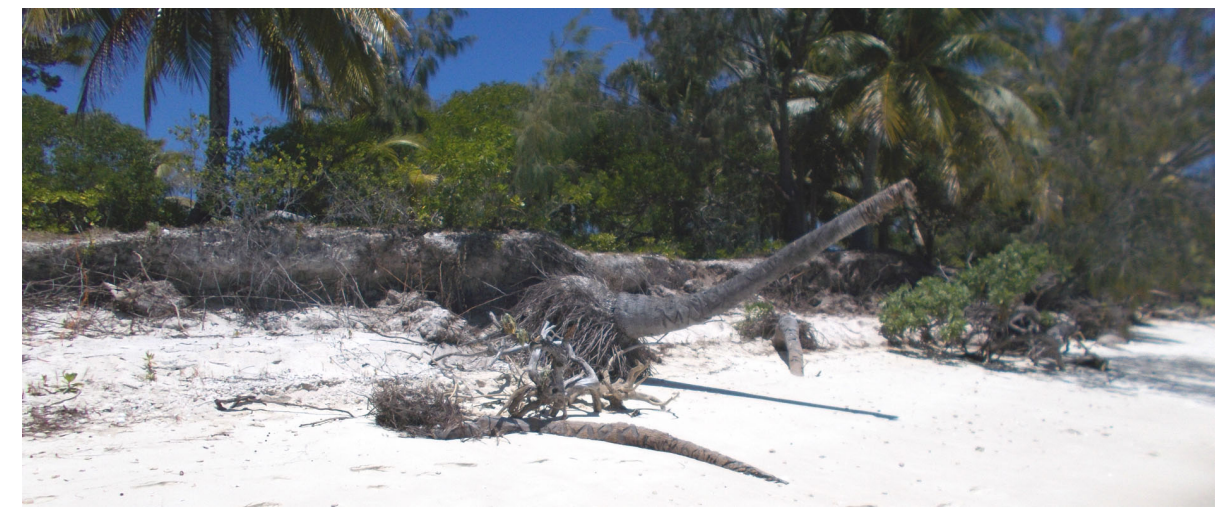

Figure 42 . Erosion at the shore $1.5 \mathrm{~km}$ to the NW of St. Joseph (with present washing limit intact, however).

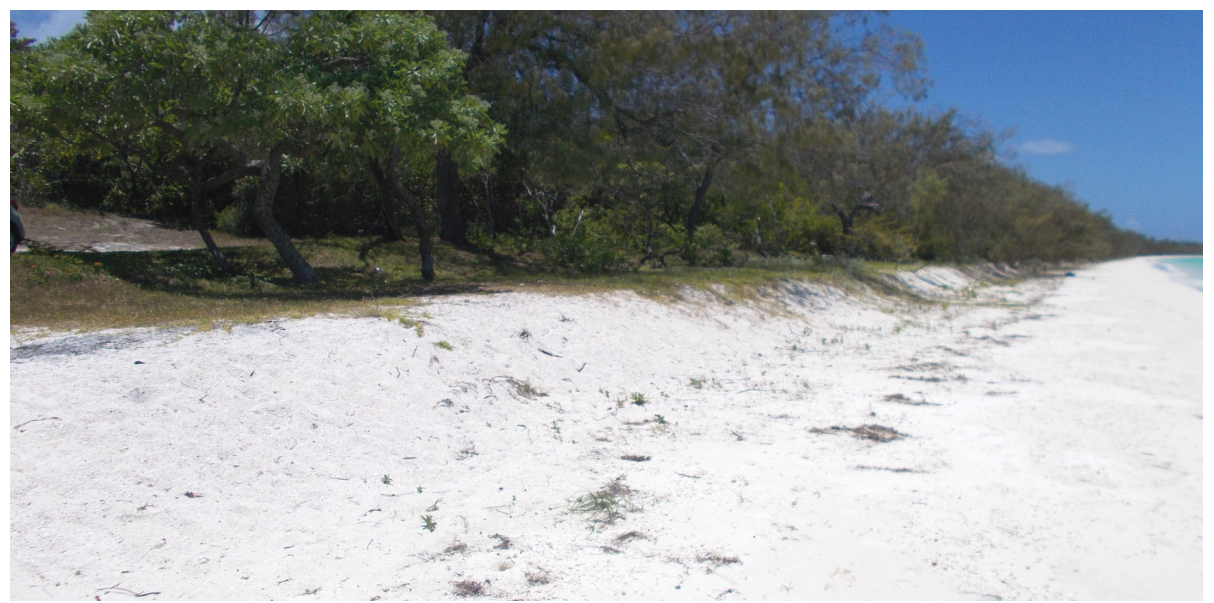

Figure 43. A stable shore segment $2-3 \mathrm{~km} \mathrm{NW}$ of St. Joseph. The present washing limit ends in a 50 $\mathrm{cm}$ slope to a second shore of sub-recent age ending in a slope, too. 


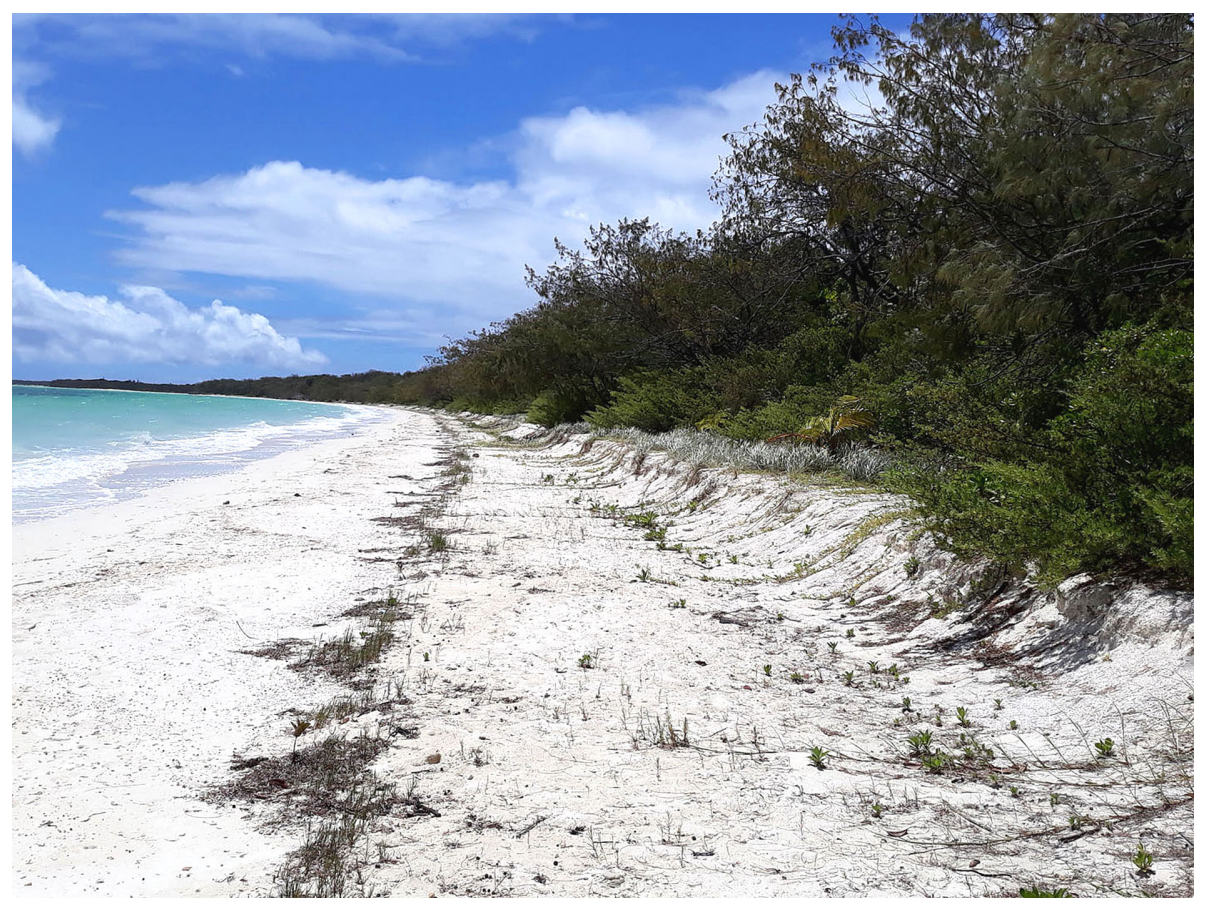

Figure 44. The shore $3.7 \mathrm{~km} \mathrm{NW}$ of St. Joseph at November 14, 2018. This photo lends clear evidence that sea level is not in a rising mode along the St. Joseph Bay of Ouvéa Island [1], at least not in 2016-2018. The difference in former and presently active washing is $2 \mathrm{~m}$ horizontally and $5-10 \mathrm{~cm}$ vertically.

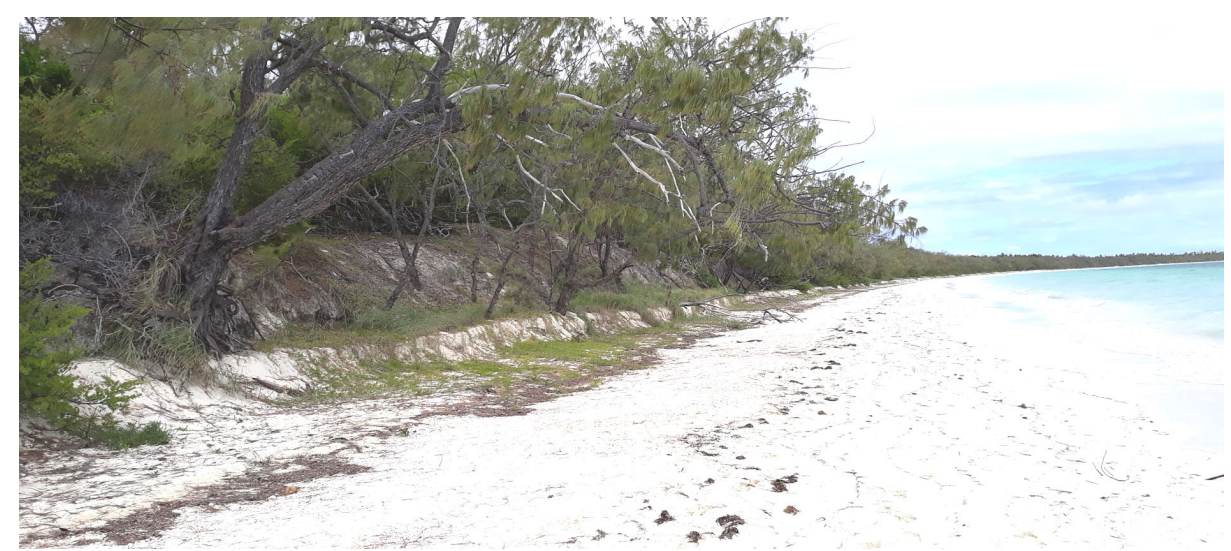

Figure 45. The shore $4.5 \mathrm{~km}$ from St. Joseph showing: a HTL, a presently active washing zone, a presently partially over-grown washing zone, a $60 \mathrm{~cm}$ notch rising from $+10 \mathrm{~cm}$ to $+70 \mathrm{~cm}$ (above present $\mathrm{WL}$ ), and an over-grown sub-recent shore at $+70 \mathrm{~cm}$ ending in a eolian dune ridge.

\subsection{Site 19 and the Inland "Sea"}

At the entrance to the "St. Joseph inland sea", there are morphological facts indicating a recent lowering in sea level of about $20 \mathrm{~cm}$ (Figure 46). There are also higher shore surfaces ranging from +40 to +70 $\mathrm{cm}$, which seems to link them to the $+70 \mathrm{~cm}$ sub-recent sea level position. The changes in sea level at the entrance are, of course, directly linked to the changes within the inland sea system itself.

The northwest part of the St. Joseph district contains a remarkable "inland sea" system (Figure 47). Obviously, it represents the flooding of an old river system (probably dating back to the last Ice Age sea 


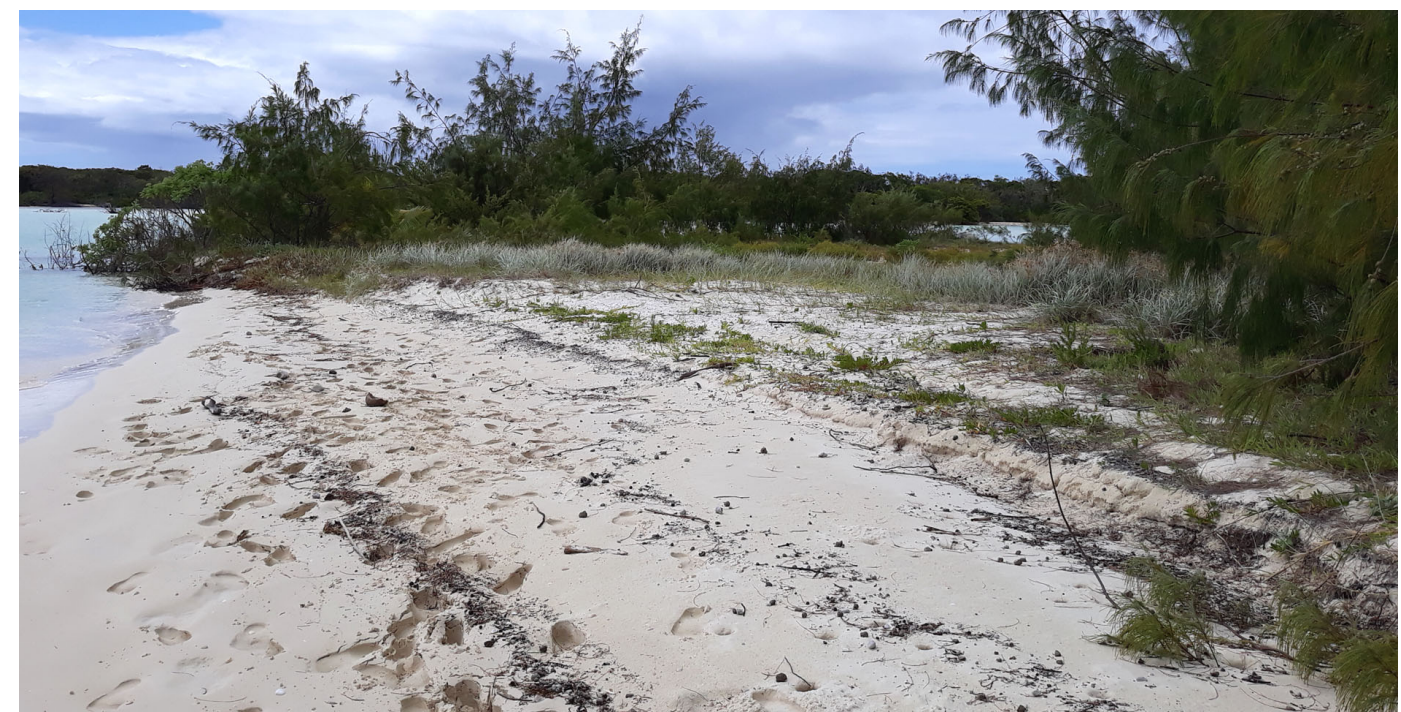

Figure 46. The NW point at the inlet to the "St. Joseph inland sea". The present washing limit ends at a small scarp of $20-40 \mathrm{~cm}$ to a former shore plane. This calls for a minor sea level lowering in recent to sub-recent time. Note present erosion of the former island, despite the present regressive trend [12].

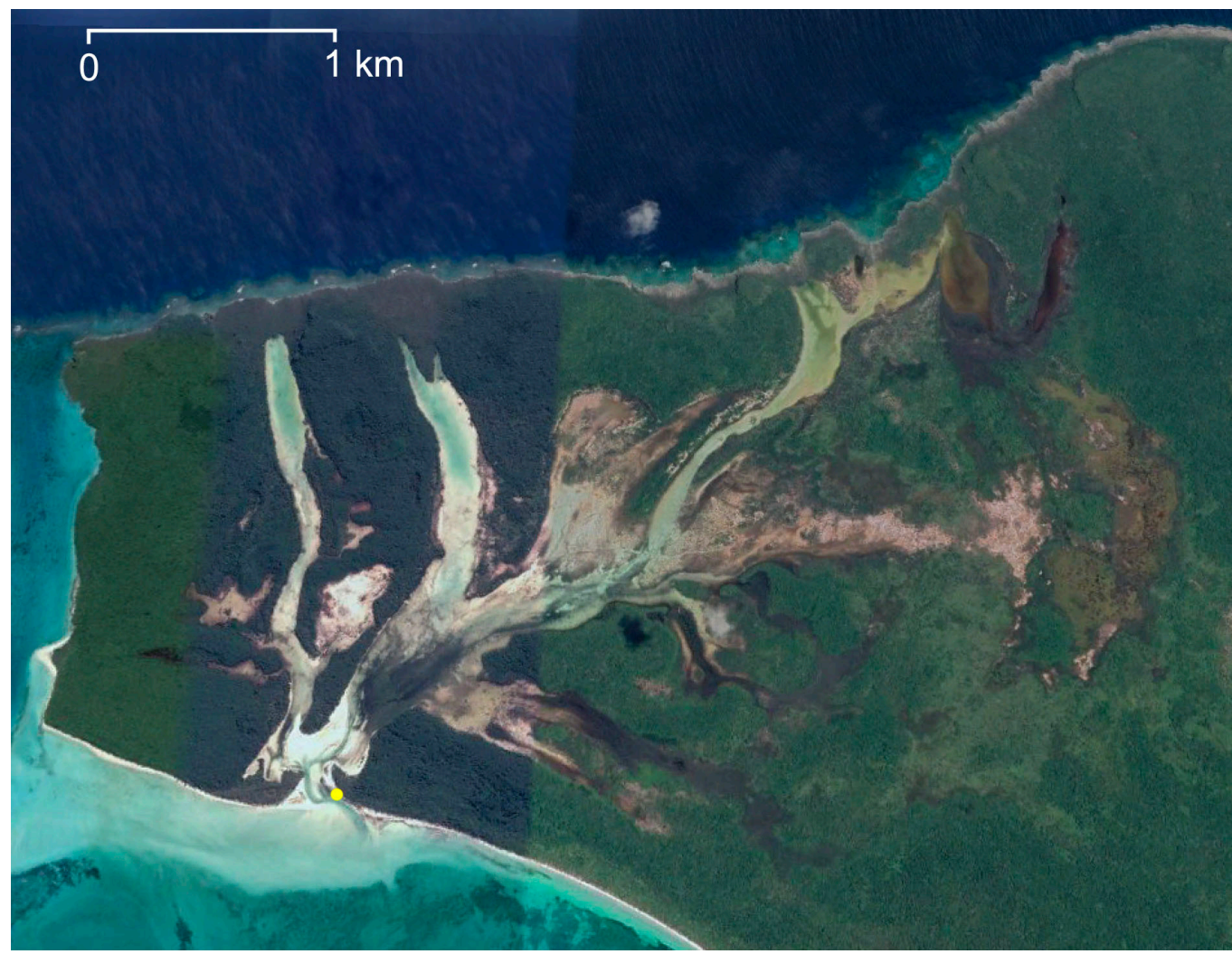

Figure 47. The "St. Joseph inland sea": a branching "tree" of water arms reaching nearly $4 \mathrm{~km}$ inland. Yellow dot at entrance marks the location of Figure 45. The water branches seem successively to dry up inland. This can only be understood in terms of a recent sea level lowering (as observed at the entrance, Figure 45). 
level lowstand). Today, it is in the process of shrinking and growing-over. This seems to be a function of a lowering in sea level in recent time by about $10-20 \mathrm{~cm}$ and/or the $70 \mathrm{~cm}$ lowering after the sub-recent +70 $\mathrm{cm}$ sea level.

The eastern and southern branches seem most affected, and partly lack water (black and brown on the Figure 47 image).

\subsection{The Unyee Island and Its Inland "Sea"}

Unyee Island hosts a huge "inland sea" system (Figure 48) from a former fluvial drainage system, later flooded by the postglacial rise in sea level. Today, the entrance is blocked. Local people (Fréféric and Laura Waikata) told me that they previously were able to access the "inland sea" from the sea, and on the local tourist map, it is drawn with an open connection to the sea.

This late closure of the entrance, is consistent with a recent lowering of sea level by about $10-20 \mathrm{~cm}$ as observed in morphology (Figure 44 and Figure 46) and coral growth (Figure 37).

Furthermore, the "Unyee inland sea" system exhibits signs of becoming shallower and, in the eastern part, even of becoming over-grown: i.e. both indications of a sea level lowering.

\subsection{The Holocene, Sub-Recent and Present Sea Levels: A Summary}

A Mid to Late Holocene sea level high-stand is often recorded elsewhere. In Ouvéa Island traces of such a level were only recorded as rock-cut platforms at Site 1 at about $+1.5-1.9 \mathrm{~m}$, and at Site 12 at +1.5 $\mathrm{m}$. Sandy ridges up to +3.4 and $3.6 \mathrm{~m}$ were found in Sites 13,15 and 16. In most sites, there is a general lack of traces of a Holocene optimum shore (for example in the Lekiny key site, Figure 33).

There are overwhelming records of sub-recent sea level at $+70 \mathrm{~cm}$. Rock-cut platforms were recorded at Site 1, 17, and 12. Sandy terraces at $+70 \mathrm{~cm}$ were recorded at Sites $6,16,15,3,4,13,9,8,18$ ). At Site 6, there is a close relation between the present shore and the $+70 \mathrm{~cm}$ shore, indicating a young (sub-recent) age of the $+70 \mathrm{~cm}$ shore. The $+70 \mathrm{~cm}$ sand plane at Site 9 has a $20 \mathrm{~cm}$ humus soil, indicating centuries of formation. At Site 7, there is a shore mark at $+70 \mathrm{~cm}$. In the Lekiny Cliff section (Site 5), there is a distinct notch and shore bench at $+70 \mathrm{~cm}$ above present HTL. In the roof a number of stalactites were observed with stalagmite coating on the bench below, indicating sub-aerial conditions and a probable time of formation on the order of centuries. The existence of a $+70 \mathrm{~cm}$ shore of sub-recent age seems quite solid [9] and matches our observations in Fiji very well $[13,14]$.

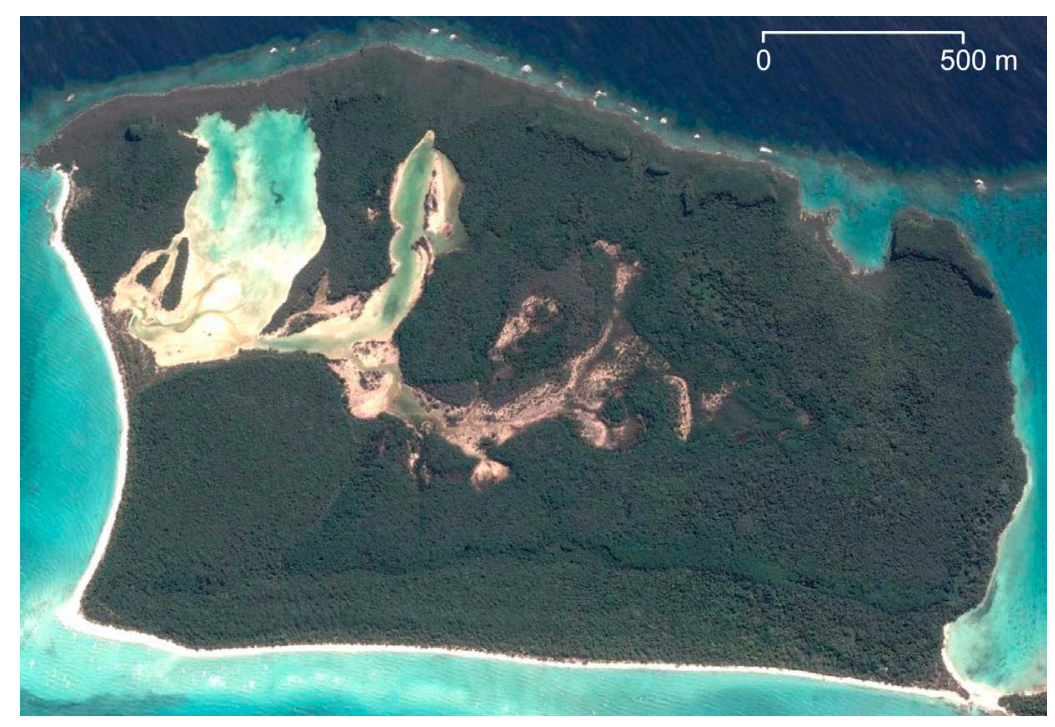

Figure 48. The "Unyee inland sea" has no open connection to the sea today. This was not the case earlier, however, when it was possible to enter the inland sea system by boat. 
The present sea level is not in a rising mode judging from the shore morphology at Sites 16, 8, 18 and 19. The Figure 44 and Figure 45 records are quite conclusive [1], cf. [14]. The corals forced to grow as micro-atolls indicate an absence of present rise in sea level, and probably even a minor lowering in recent time. A recent lowering in sea level is recorded (Figure 46) at the entrance to the "St. Joseph inland sea". Recent sea level lowering, over-growing and drying-up are recorded in the "Lekiny Bay estuary" (Site 7), the "St. Joseph inland sea" and the "Unyee inland sea".

\section{DISCUSSION}

The paper is based on stratigraphy and detailed shore morphological criteria, which have been tested as successful means of reconstructing past sea level changes $[2,15]$. These data are extensive both for the interglacial levels (Section 4 with summary in 4.7) and the Holocene to present levels (Section 5 with summary in 5.16). There is a major lack of dating, however (which is a function of economy, and the Swedish rule that retired university professors cannot receive research money unless they are still working at a university).

The +22 m shore-marks represent a higher sea level. At that time, the land area was restricted at a number of small, primarily elongated, land ridges. The age is unknown. It might represent the 3 ma warm peak with high sea level [8] or the marine isotopic stage 11 at about $400 \mathrm{ka}$, which is said to have had a sea level in the order of $+20 \mathrm{~m}[18,19]$.

The big shore notch in the Lekiny Cliff is bounded by the rock-cut platform at $+4 \mathrm{~m}$ and the top of the roof at $+13 \mathrm{~m}$ (Figure 7). The main under-cut notch seems to occur at about $+8-9 \mathrm{~m}$ (a measure gave $8.5 \mathrm{~m}$ ). Other internal notches in the Lekiny Cliff were measured at $+5.6 \mathrm{~m}$ and $+6.3 \mathrm{~m}$, suggesting the occurrence of multiple sub-levels which might correlate with the "double notches" at Cape St. Hillaire (Figure 11). At Site 6 (Section 4.6) the main rock-cut platform grades over into a shore notch at $+5.9 \mathrm{~m}$, which may suggest that the shore level at about $+6 \mathrm{~m}$, in fact, belongs to the $+4 \mathrm{~m}$ platform. This is also suggested by the fact that the $+8-9 \mathrm{~m}$ level forms a single notch (Figure 12) at Cape St. Hillaire and the $+6 \mathrm{~m}$ notch is cut into the cliff of the $+4 \mathrm{~m}$ rock-cut platform (Figure 11).

The $+4 \mathrm{~m}$ rock-cut platform (with the floor of the sea cave at $+4.3 \mathrm{~m}$, Figure 8 ) is both clear and very extensive (Figure 14), being recorded at so many different sites around the island. At Site 17, a shell from the reef was C14-dated at $>40,000 \mathrm{BP}$.

Without absolute dates, the ages of the $+8-9$ shore and the +4.3 shore can only be proposed by logic. They are both likely to represent the Last Interglacial, and more precisely the isotopic stages $5 \mathrm{e}(+8-9 \mathrm{~m})$ and $5 \mathrm{a}(+4.3 \mathrm{~m}$ with its associated $+6 \mathrm{~m}$ shore). Both stages were followed by a change in climate to a period of intensive karst weathering with the formation of huge stalactites in the $+8-9$ under-cut notches (Figure 7 and Figure 32) and with the formation of deep dissolution holes in the $+4 \mathrm{~m}$ rock-cut platform (Figure 10). These climate conditions seem to represent the time of the Last Ice Age.

It is surprising to find so few remains of a Holocene sea level high-stand, only the strongly weathered reef plans at Sites 1 and 17 at about $+1.5 \mathrm{~m}$, and sand ridges reaching $+3.4-3.6 \mathrm{~m}$.

The $+70 \mathrm{~cm}$ sea level is quite thoroughly documented throughout the entire island. The Site 17 rock-cut platform (Figure 38 and Figure 39) is quite convincing both as a former sea level position and of a sub-recent age. In the Fiji Islands, a former sea level position was recorded at the same height with absolute dating at the $17^{\text {th }}$ century $[13,14]$.

In this paper, numerous facts are presented indicating that sea level is presently not in a rising mode at Ouvéa Island [1]. Although contrary to popular claims of a globally rising sea level [10, 20], this observation is firmly anchored in local stratigraphy, shore morphology, estuary ecology and coral growth. Besides, it agrees with observations in the Fiji Islands [14].

\section{A Note on Tectonics}

This paper is about observational facts as documented in the field. Still. it seems appropriate to add a few notes on tectonics (cf. Section 2). The Ouvéa Island represents an active tectonic area; a fact to con- 
sider, but not a fact precluding semi-stable conditions today.

Ouvéa Island is a part of the Loyalty Ridge (Figure 4). With a basement of volcanic rocks, chalk, basalt, limestone of Oligocene to Miocene age and reefs of Late Miocene to Pleistocene age [3]. The sea level for New Caledonia as a whole was proposed [4] to be in the order of $+4-6 \mathrm{~m}$ occasionally up to $10 \mathrm{~m}$ for the Last Interglacial and from zero to $+2 \mathrm{~m}$ for the Mid-Holocene.

In the high area between Sites 11 and 12 (Figure 6), there is a quarry for limestone. It includes banks of molluscs, and some corals, too. The upper part in the Lekiny Cliff (Figure 7) from about $+22 \mathrm{~m}$ to the top seems to consist of limestone (though inaccessibility prevented a close inspection). The highest point on Ouvéa is said to reach $+43 \mathrm{~m}$. The limestone deposits are likely to represent an early now uplifted phase.

Without absolute dating it becomes too speculative to try to interpret the $+4-6 \mathrm{~m}, 8-9 \mathrm{~m}$ and $+22 \mathrm{~m}$ levels in terms of tectonics. But it should be stressed that there is no direct need of calling for any significant tectonic deformation.

Another issue is whether there are internal tectonic variations between different parts of the Ouvéa Island, and no such differentiation seems possible to observe. Instead there seems to be a good consistency in the $+4 \mathrm{~m}$ shore, the $+8-9 \mathrm{~m}$ shore, the $+22 \mathrm{~m}$ shore, and especially in the sub-recent $+70 \mathrm{~cm}$ level from the south to the north of Ouvéa. Furthermore, just the same tendency of a present stability to lowering in sea level is recorded in the south (Sites 5 and 7) as in the north (Sites 18, 19, Unyee).

\section{CONCLUSIONS}

The $+22 \mathrm{~m}$ shore seems old, and might perhaps dates from the $3 \mathrm{ma}$ warm period and high sea level (e.g. [8]), or it might represent a Mid to Early Pleistocene interglacial high-stand, preferably isotopic stage 11 (e.g. [18]). This is for future investigation to decode.

The $+8-9$ m notch and $+4 \mathrm{~m}$ platform are often closely linked together (as in the Lekiny Cliff section). Therefore, it seems natural to interpret both levels in terms of records of the Last Interglacial (isotopic stages $5 \mathrm{e}$ and $5 \mathrm{a}$ ).

A period of intensive karst activity (stalactites in the $+8-9$ m under-cut notch, and deep dissolution holes in the $+4 \mathrm{~m}$ rock-cut platform), indicating a major change in climate; most likely the Last Ice Age period.

There are only limited remains of a Holocene sea level high-stand. The level observed is on the order of $+1.5 \mathrm{~m}$ (in agreement with earlier estimates [4], however).

There are extensive records of a $+70 \mathrm{~cm}$ sea level of sub-recent age. In Site 6, there is a close morphological connection between the present shore processes and those of the $+70 \mathrm{~cm}$ shore (Figure 23). The rock-cut platforms in Sites 1, 17 and 12 are quite impressive (Figures 38-40). Stalactites and stalagmite coating of the $+70 \mathrm{~cm}$ shore bench (Figure 36), and soil formation on the +70 sand terrace at Site 9 (Figure 41), indicate an age in the order of a couple of centuries, which fits with the dates from the $17^{\text {th }}$ century of the $+70 \mathrm{~cm}$ level documented in Fiji $[14,15]$, the $+60 \mathrm{~cm}$ level in Goa $[2,16]$ and the $+50 \mathrm{~cm}$ level in the Maldives $[2,17]$.

The absence of a present rise in sea level is very clear in shore morphology (Figure 44 and Figure 45), stratigraphy (Figure 46), coral growth (Figure 37), and the drying-up tendency recorded in the "Lekiny Bay estuary" (Figure 28), the "St. Joseph inland sea" (Figure 47) and the Unyee inland sea" (Figure 48).

With this observational material, it is my sincere hope that followers will solve remaining dating problems, and utilise the sites here described for further studies.

\section{ACKNOWLEDGEMENTS}

I am indebted to a number of local persons who assisted me in my work on Ouvéa Island: Pierre Thomas Wachou at the Tourist Information, who helped me with a lot of information and advices, even some photos; Mathius Waneux who guided me for a long walk at Cap St. Hilaire (Site 14) where excellent shore data were collected, and Fréféric and Laura Waikata who provided information and advices. My 
sincere thanks to Dr. Pamela Matlack-Klein for professional linguistic updating.

\section{CONFLICTS OF INTEREST}

The author declares no conflicts of interest regarding the publication of this paper.

\section{REFERENCES}

1. Mörner, N.-A. (2018) Absolute Evidence of the Absence of an On-Going Sea Level Rise on Ouvéa Island of New Caledonia. International Journal of Geoinformatics and Geological Science, 5, 30-33. https://doi.org/10.14445/23939206/IJGGS-V5I3P104

2. Mörner, N.-A. (2019) Rotational Eustasy as Observed in Nature. International Journal of Geosciences, 10, 745-757. https://doi.org/10.4236/iig.2019.107042

3. Pelletier, B. (2007) Geology of the New Caledonia Region and Its Implications for the Study of the New Caledonian Biodiversity. In: Payri, C.E. and Richer de Forges, B., Eds., Compendium of Marine Species of New Caledonia, Second Edition, Doc. Sci. Tech. II7, IRD, Nouméa, 19-32.

4. Anddréfouët, S., Cabioch, G., Flamand, B. and Pelletier, B. (2007) The Diversity of New Caledonia Coral Reef Geomorphology and Genetic Processes: A Synthesis from Optical Remote Sensing, Coring and Acoustic Multi-Beam Observations. In: Payri, C.E. and Richer de Forges, B., Eds., Compendium of Marine Species of New Caledonia, Second Edition, Doc. Sci. Tech. II7, IRD, Nouméa, 33-49.

5. Falefou, T. (2015) Discussing Climate Change in New Caledonia. University of Waikato, Hamilton. https://www.waikato.ac.nz/news-opinion/media/2015/discussing-climate-change-in-new-caledonia

6. Le Duff, M., Allenbach, M., Dumas, P. and Cohen, O. (2015) Shoreline Evolution in Ouvéa Island (New Caledonia). UNC University, Chapel Hill. https://www.researchgate.net/publication/284452222_Shoreline_evolution_in_Ouvea_island_New_Caledonia_ A_dic_approach_using_past_long_term_data_A_method_for_a_middle_term_in_field_measurements_for_the future

7. Pecquet, S. (2018) Ouvéa, a Fragile Paradise. Earth Journalism Network. https://earthjournalism.net/stories/ouvea-a-fragile-paradise

8. Mörner, N.-A. (2018) Development of Ideas and New Trends in Modern Sea Level Research: The Pre-Quaternary, Quaternary, Present and Future. In: Ramkumar, M., et al., Eds., Coastal Zone Management. Global Perspectives, Regional Processes, Local Issues, Elsevier, Amsterdam, Chapter 2, 13-62. https://doi.org/10.1016/B978-0-12-814350-6.00002-1

9. Mörner, N.-A. (2018) The Kattegatt and the Baltic as Test-Areas of Absolute Sea Level Changes, and an Excellent New Record from New Caledonia Indicating Absence of a Present Sea Level Rise. 12th International EIKE Conference on Climate and Energy and 13th International Conference on Climate Change, München, 23-24 November 2018.

10. Pacquet, S. (2018) Ouvéa, a fragile paradise. A project of Internews. 17 p. https://earthjournalism.net/stories/ouvea-a-fragile-paradise

11. Mörner, N.-A. (2018) Coastal Dynamics. In: Makowski, C. and Finkl, C., Eds., Encyclopedia of Coastal Sciences, Springer, Berlin. https://doi.org/10.1007/978-3-319-48657-4_374-1

12. Mörner, N.-A. and Finkl, C. (2018) Coastal Erosion. In: Makowski, C. and Finkl, C., Eds., Encyclopedia of Coastal Sciences, Springer, Berlin. https://doi.org/10.1007/978-3-319-48657-4_374-1

13. Mörner, N.-A. and Matlack-Klein, P. (2017) New Records of Sea Level Changes in the Fiji Islands. Oceanography \& Fishery, Open Access Journal, 5, Article ID: 555666. https://doi.org/10.19080/OFOAJ.2017.05.555666 
14. Mörner, N.-A. (2017) Our Oceans-Our Future: New Evidence-Basted Sea Level Records from the Fiji Islands for the Last 500 Years Indicating Rotational Eustasy and Absence of a Present Rise in Sea Level. International Journal of Earth \& Environmental Sciences, 2, 137. https://doi.org/10.15344/2456-351X/2017/137

15. Mörner, N.-A. (2019) Biology and Shore Morphology: Keys to Proper Reconstruction of Sea Level Changes. Journal of Marine Biology and Aquascape, 1-020. http://dx.doi.org/10.31579/26415143/JMBA.2019/020

16. Mörner, N.-A. (2017) Coastal Morphology and Sea-Level Changes in Goa, India, during the Last 500 Years. Journal of Coastal Research, 33, 421-434. https://doi.org/10.2112/JCOASTRES-D-16A-00015.1

17. Mörner, N.-A. (2007) Sea Level Changes and Tsunamis, Environmental Stress and Migration Overseas. The Case of the Maldives and Sri Lanka. Internationales Asienforum, 38, 353-374.

18. Olson, S.L. and Hearty, P.J. (2008) A Sustained $+21 \mathrm{~m}$ Sea-Level Highstand during MIS 11 (400 ka): Direct Fossil and Sedimentary Evidence from Bermuda. Quaternary Science Reviews, 28, 271-285. https://doi.org/10.1016/j.quascirev.2008.11.001

19. Bowen, D.Q. (2010) Sea Level-400,000 Years Ago (MIS 11): Analogue for Present and Future Sea-Level? Climate of the Past, 6, 19-29. https://doi.org/10.5194/cp-6-19-2010

20. IPCC (Intergovernmental Panel on Climate Change) (2013) Climate Change. Intergovernmental Panel on Climate Change, Fifth Assessment Report. Cambridge University Press, Cambridge, 1535 p. https://doi.org/10.1017/CBO9781107415324 